\title{
Checking the Sea: Geographies of Authority on the East Norfolk Coast,
}

\section{0-1932}

\author{
David Matless \\ University of Nottingham \\ Email: David.Matless@Nottingham.ac.uk
}

\begin{abstract}
This paper examines coastal defence in east Norfolk between the late-eighteenth and earlytwentieth centuries. From 1802 until 1932 sea defence between Happisburgh and Winterton was the responsibility of the Commissioners of Sewers for the Eastern Hundreds of Norfolk, more commonly known as the Sea Breach Commission (SBC). This paper explores the geographies of authority shaping sea defence, with the SBC a body whose relationship to the local and national state could be uneasy. The paper outlines the SBC's nineteenth century roles and routines, and examines its relationship to outside expertise, including its early hiring of geologist William Smith. The paper reviews challenges to the SBC's authority following latenineteenth century flood events, details its early-twentieth century routines, and examines disputes over development on the sandhills. The paper details the SBC's dealings with an emerging national 'nature state', around issues such as coastal erosion and land drainage, matters which led to the SBC's demise following the 1930 Land Drainage Act. The paper concludes by considering the SBC's contemporary resonance in a time of challenges to the role of the nature state, and anxieties over coastal defence.
\end{abstract}

\section{Geographies of Authority}

When sea meets land, people may become concerned for the consequences; those who live nearby, those who make a living thereby, those who seek scientific understanding, or those who visit, and are curious as to what might be happening to a place they enjoy. Some claim or are granted formal authority over coastal process, marked out by technical knowledge, local connection, ownership of property, or some combination thereof. Stretches of coast come under legal, intellectual and emotional jurisdiction, with consequent acts and disputes.

Between 1802 and 1932 the authorities for around ten miles of coast in east Norfolk, England, were the Commissioners of Sewers for the Eastern Hundreds of Norfolk, more commonly known as the Sea Breach Commission (SBC). The SBC were established in 1802 and charged with checking the sea until the 1930 Land Drainage Act re-constituted powers around Internal Drainage Boards and Catchment Boards. Sections of the 1930 Act indeed help explain the SBC's distinctive full title: 'Under the repealed legislation the term 'sewer' included a defensive bank'.1 
The SBC checked the sea in two senses, monitoring and countering, seeking to prevent sea flood on a low-lying coast, where a line of sandhills protected extensive marshland. The northern section of the SBC's patch between Happisburgh and Eccles included low sand cliffs, but the remainder saw narrow dunes south to Winterton, before a more extensive dune system took over at Winterton Ness. The small settlements of Eccles, Sea Palling, Waxham and Horsey lay behind the dune line, barely above sea level. The historical record showed repeated breaches, from floods in 1287 when 108 died at Hickling, through further major breaches in 1608, 1617, $1622,1717,1718,1720$ and 1791. From 1609-1743, as Barbara Cornford has detailed, temporary Sea Breach Commissions had periodically overseen defence, but the SBC was the first such permanent body. ${ }^{2}$

Sea defence on the SBC's patch was at once a local and regional matter. Breaches in the dunes had potential effect far beyond the immediate coastal zone, and while the SBC's work was coastal, its membership and revenue was also derived from inland. The particular geography and topography of the region is conveyed well in Patrick Bailey's 1971 regional 'sketch panorama ... from a theoretical viewpoint off Great Yarmouth', taken from his book on The Norwich Area in the Geographical Association's 'British Landscapes Through Maps' series. ${ }^{3}$

\section{[FIG.1]}

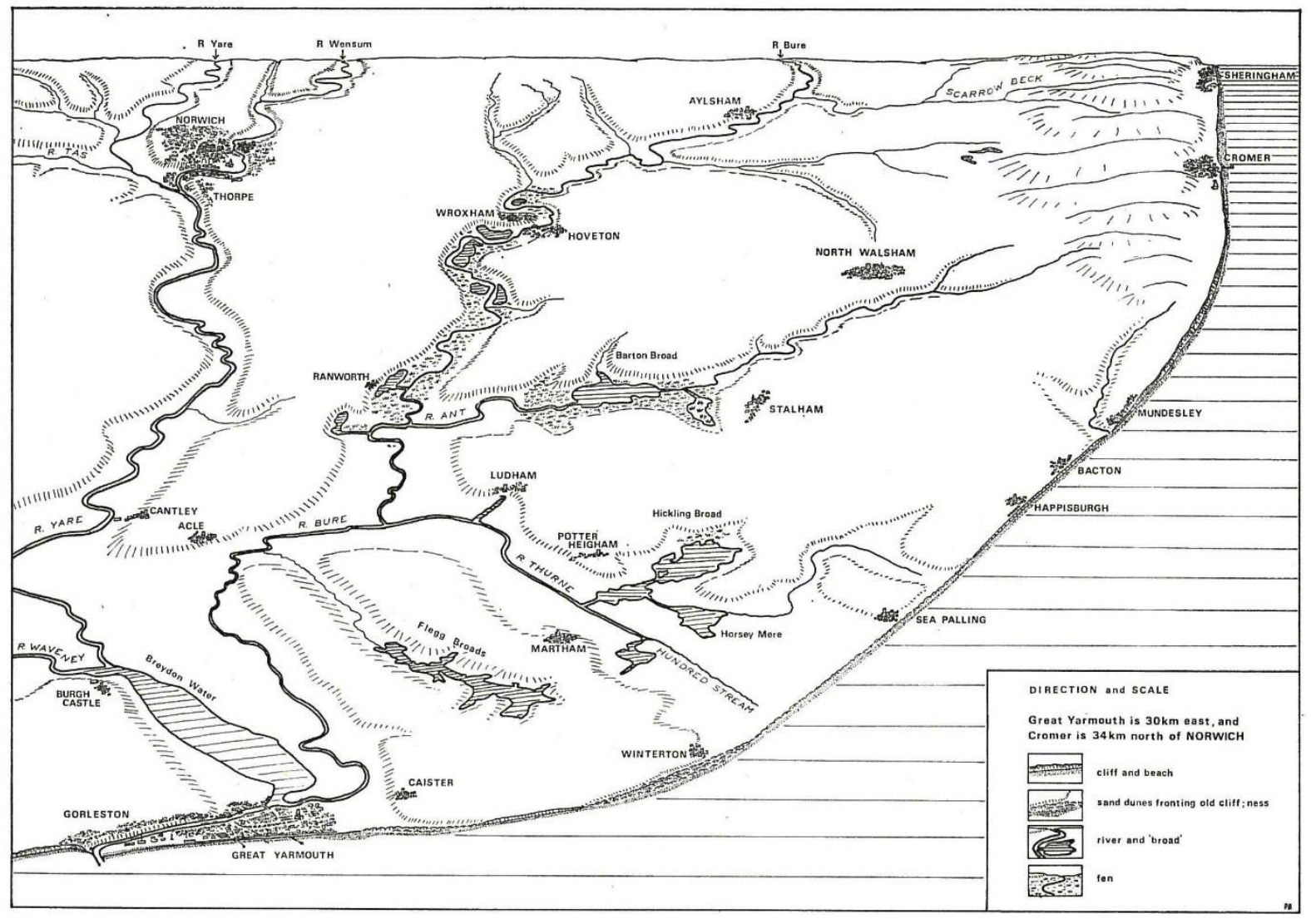


The map indicates how significant coastal flooding between Happisburgh and Winterton might affect the valleys of the Thurne, Bure, Ant, Yare and Waveney, salt water potentially moving up to Wroxham and Norwich and down to Breydon Water, and the river system's sea exit at Great Yarmouth. ${ }^{4}$ Here was an evidently vulnerable coast, sea flood threatening life and property, with what Franz Mauelshagen, in his study of the German North Sea coast, terms 'the expectation of repetition'.5 Understandings of historical events indeed informed the actions of the SBC.

As a staunchly local body, its entirely male membership drawn from coastal and inland landowners whose property might be affected by sea flood, the SBC demonstrates geographical tensions around the management of coastal change, and the scales at which at the sea might be checked. This paper offers a micro-study of defence and erosion over 140 years, outlining the formation of the SBC, the constitution of its expertise, its routines of work, critiques of its performance, and the geographies of its authority. ${ }^{6}$ East Norfolk displays key nineteenth and early twentieth century coastal themes, which remain pertinent today; the standing of local control and advice, the connection between sea defence and land values, and debates over defence strategy. Should the sea's power be met with hard engineering structures, or should defence work with natural process? For the SBC working with nature appeared both a philosophical and economic choice, effective and relatively cheap, their guiding principle set out by surveyor Robert Pratt in 1836: 'Nature may be assisted, but can seldom if ever be improved by endeavouring to alter or change her course'.7

The SBC operated in their own patch, without oversight. As Commissioners of Sewers however they were part of a national institutional history of drainage and flood management, with longstanding tensions surrounding operational independence, organisational inertia, and differences of national and local ambition. Commissions of Sewers had been appointed by the Crown since the medieval period, geographically and temporally circumscribed, dealing with challenges of drainage and water management. Hilda Grieve's 1959 The Great Tide, a major study of the 1953 sea floods in Essex, discusses their historical coastal role, but Commissions have received greatest historical attention for their inland drainage functions. ${ }^{8}$ Eric Ash's 2017 The Draining of the Fens builds on Clifford Darby's 1940 The Medieval Fenland and The Draining of the Fens, Ash highlighting the key role of local knowledge in shaping interlocking and sometimes rival scales of authority. ${ }^{9}$ Commissions set up from the thirteenth century to facilitate local drainage became viewed as impediments to progress when drainage 'projectors' and the Crown sought regional-scale schemes in the seventeenth century. Commissioners of Sewers could be labelled as narrowly parochial, just as the SBC would be over its lifetime, and as signifying chaotic administration, a local patchwork frustrating regional and national ambition. 
Ash presents the Commissions as 'fundamentally local and conservative in nature', their local knowledge deemed a source of authority by their proponents, but a marker of parochialism by their detractors..$^{10}$ Visionary projects proceeded (or failed to proceed) in counterpoint to what Darby terms 'the diligent and humdrum labours of successive generations of commissioners battling against the difficulties of drains and outfalls'.11 The implementation of visionary regional schemes in the seventeenth century, and the subsequent challenges of peat shrinkage and channel management, would lead to further multiple reconfigurations of authority, which remained in place until the 1930 Land Drainage Act. For Darby: 'In the post-drainage Fenland, as in the pre-drainage Fenland, there was everywhere a chaos of authorities and an absence of authority'.12

As noted above, the SBC were distinctive in that their local coastal management was a matter of inland regional flood defence, and the complexities of scale in their work will be addressed below. The Fenland criticisms of inertia, parochialism and amateurism all play out here, but with a twist from the particular geographical circumstances of east Norfolk, and from the SBC's own claims to scientific authority against those favouring harder engineering solutions. Existing historical studies tend not to give sustained attention to the work of one Commission, but geographical concentration here allows appreciation of the human workings of an institution, shaped by internal differences and individual personalities, and of modes of attentiveness and enactments of authority over the coast across 140 years. Micro-geography demonstrates macro themes, playing out on Norfolk dunes.

The SBC's geographies of authority are pertinent to what Kelly, Leal, Wakild and von Hardenberg have termed the historical emergence of a managerial 'nature state', marked by 'the claims the state makes over its constitutive lands, waters and species of plants and animals, with ramifying effects throughout human and non-human histories'. In their account the nature state appears a formation of the 'long twentieth century', though they envisage the category being of use for analysing earlier periods. ${ }^{13}$ The SBC, and Commissions of Sewers in general, indeed show how the nature state idea might project back, yet in the process gain new complexity, which might in turn complicate the twentieth century story. The SBC stands within a longer history of Crown-appointed institutions, which survived into the twentieth century alongside an emerging modern nature state. As a publically constituted yet operationally independent body, with a strong sense of its own geographical distinction, by the twentieth century the SBC occupied a space in between private property rights and emerging national state regulation. The SBC's actions over its constitutive lands and waters could, on the one hand, be presented as infringing on private landowners, yet on the other as asserting local 
independence against moves to make sea defence and land drainage national. Older and newer forms of governance meet in dispute. Constitutionally hybrid and geographically circumscribed, the SBC maintained its own patch, and itself, for 130 years. After the First World War, national moves to organise land drainage would eventually swallow the SBC.

Kelly, Leal, Wakild and Von Hardenberg note the work of David Blackbourn on water and landscape in modern Germany as informing their concept of the nature state. Blackbourn titled his 2006 book The Conquest of Nature, 'because that is how contemporaries described what they were doing', with combatting flood and draining land one aspect of nature conquest, enfolded within human power relationships: 'Look at how German waterways were remade, and you see where the lines of power ran. The human domination of nature has a lot to tell us about the nature of human domination'. ${ }^{14}$ Blackbourn also notes, in his study of North Friesland coastal works, the capacity of the sea to upset human schemes: 'Floods continued to add their counterpoint to the process of land reclamation from the sixteenth century into the nineteenth'.15 The SBC inhabited a similarly contrapuntal space, asserting their particular variant of local power, although their relationship to natural forces was presented less as one of 'conquest' than of co-operation, guiding sea forces to enhance coastal security. The SBC presented themselves deploying modest technologies, their geographies of engineering authority enacted via marram grass and thorn faggots rather than grand controlling schemes of walling and embankment.

The SBC staked out their territory, claimed authoritative knowledge, exercised jurisdiction and countered critics, in the process performing a particular mode of authority. In his performative accounts of the drainage landscapes of north Lincolnshire, Mike Pearson shows how authority is performed through acts of construction, reportage, analysis and routine. This paper takes from Pearson's careful reading of Lincolnshire's 'carrlands' and 'warplands' a cue to attend to routine statements of inspection and maintenance as key elements of the performance of geographical authority. ${ }^{16}$ The paper outlines the SBC's nineteenth century roles and routines, examines its relationship to outside expertise, reviews challenges to its authority following late-nineteenth century flood events, returns to its early-twentieth century routines, details its twentieth century dealings with an emerging national nature state, and examines a late flowering of local dispute, before attending to the SBC's demise. The philosophy and economics of coastal defence continue to be debated today, in east Norfolk as elsewhere, with global concerns for sea level rise and climate change making the coast what Glavovic has termed 'the frontline in the Anthropocene'. ${ }^{17}$ The paper returns to contemporary resonances in conclusion, but begins at the end of the eighteenth century, with sea defence lacking, and sea breach frequent. 


\section{Keeping the Coast}

The SBC emerged in a context of deteriorating defences and proposals for agricultural improvement. The state of defences is conveyed in William Marshall's 1795 survey of The Rural Economy of Norfolk, where Marshall visited 'Mr. B.', owner of estates at Horsey and Waxham. 'Mr. B.' was Sir Berney Brograve of Waxham Hall, who Cornford notes 'led the pressure for a Commission',18 indeed Marshall comments: 'Mr. B__e has attempted to make the embankment a public matter; but has not succeeded. It strikes me, however, that it would be well worth his while to defend his coast at his own expence; but he says, "It is not for me to attack the German Ocean single-handed"'. ${ }^{19}$ Brograve's identity would be obvious to those knowing the area, but not naming 'Mr. B.' allowed Marshall some commentary on character: 'His person is gros, and his appearance bacchanalian'. ${ }^{20}$ Marshall noted the marram banks 'broken into gaps at every two or three hundred yards; so that in stormy weather the sea rushes through, and frequently does considerable damage by overflowing the country', and pondered possible defence strategy. ${ }^{21}$ While on Brograve's land stock moved freely from marsh to beach, adjoining proprietors had to fence the beach 'lest their cattle should stray into Mr. B__'s liberty'. Faggots thereby placed in gaps between sandhills collected blown sand: 'The effect of these faggotfences is striking ... it strikes me very forcibly, that from fences, to keep the marsh cattle from straying away upon the beach, have originated the Marram Banks'. Faggots could help convert the marrams 'into a barrier not to be broken by the sea', indeed they would become central to SBC defence work. ${ }^{22}$

After its 1802 establishment the SBC noted that breaches had 'of late years increased to an alarming degree so as to have done considerable damage to the Country adjoining and to threaten the same with the greatest danger'. ${ }^{23}$ A sketch map produced in the early-twentieth century by Commissioner Robert Gurney, derived from Faden's 1797 topographical map of Norfolk, showed 'Gaps or Breaches made by the sea in the Marum Hills prior to summer 1792', a coastline barely holding anything at bay. ${ }^{24}$ [FIG. 2] Gurney's engagement with erosion history indicates the ways in which the SBC cultivated its own institutional memory, indeed historical commentary shaped erosion debate throughout the SBC's institutional life. 


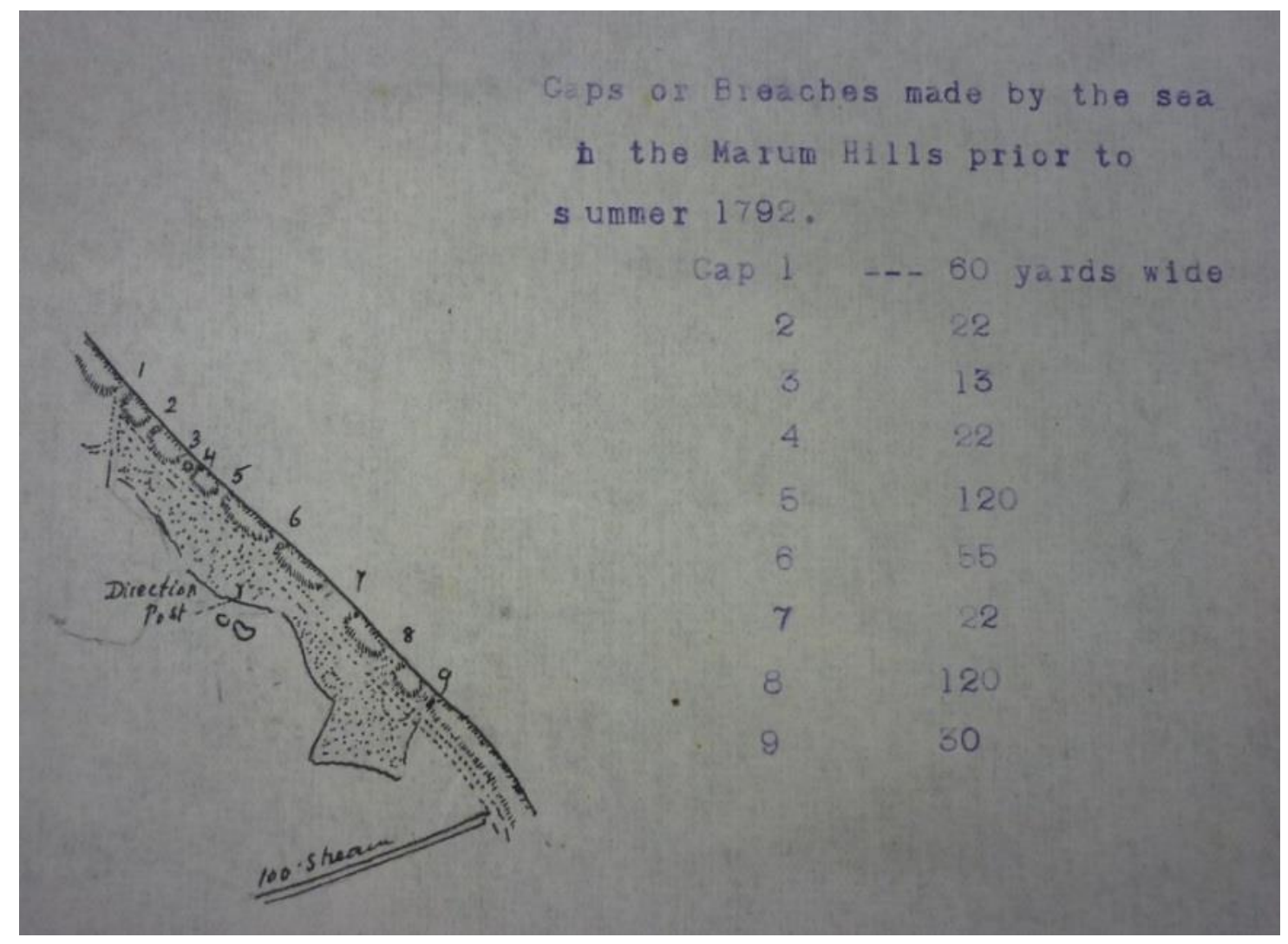

Breaches coincided with plans to enclose inland marshes, investment in land value demanding adequate sea defence. ${ }^{25}$ Grieve similarly notes that in late-eighteenth century Essex sea defence initiatives followed 'a new interest in the marshland as land fit to grow crops'. ${ }^{26}$ The SBC raised revenue via the rating of lands under the ten foot contour, over 50000 acres up to twenty miles from the dune line, rates differential according to distance. Rating reviews, in terms of territory covered and sums raised, occurred throughout the SBC's tenure, with measurement of relative sea and land levels crucial. Thus in 1907 SBC surveyor and land agent Francis Hornor noted: 'The result of the Tide Gauges set up at Eccles Beach and Horsey Beach has been most satisfactory, and the readings confirm that lands below $10 \mathrm{ft}$ above O.D. derive benefit, as in certain Gales the Gauges registered 15 feet above O.D.' Gurney added: 'The basis of this claim is that the highest tides do reach to or above $10 \mathrm{ft}$ above O.D. and that therefore all these lands are liable to inundation if the sea had access to them. That this danger is a real one is proved by past history and present experience'.27 Checking sea levels justified the SBC's territorial coverage.

The SBC physically staked out their area of defensive action. Thus in 1837 posts were erected from Happisburgh to Winterton, 200 yards apart, 'to mark the boundary under the Jurisdiction of the Commissioners'. ${ }^{28}$ Within this territory the SBC exercised direct authority, planting marram grass on sandhills, laying thorn faggots, and erecting groynes on the beach to catch drifting sand. The SBC appointed a surveyor to oversee work, with Robert Pratt, quoted above 
on working with natural process, in post between 1813 and 1826, and 1836 and the early 1840s. Pratt was a land agent, founder in 1794 in Norwich of what would become the Hornor Land Agency (after his nephew Charles Hornor, who joined in the 1850s). Pratt's east Norfolk work concerned sea defence, enclosure and drainage. The SBC also mapped their territory, the Norfolk Record Office holding scroll maps several feet in length, from 1810 and 1843, for their entire coastal stretch. ${ }^{29}$ The 'Plan of the Sea Breaches from Happisburgh to Winterton, Norfolk 1810 ' identifies and numbers breaches, shows dune widths, problems ('This Bank very much injured by the Rabbits') and actual and proposed defensive structures ('Proposed Inner Bank planted with Bramble and Marum'). On the 'Map of the Sea Banks from Happisburgh and Winterton 1843', landowners are noted. Later inscriptions also appear on the 1810 map; a 'Proposed Line of Embankment Novr 1836' behind the dunes at Waxham, 'Little or no Marum 1825' at Horsey. At Eccles Chase the 1810 map records sea breach 'No. 1', sand carted away, the crown of the bank, a proposed new bank, the work of 'Mr Smith' (discussed below), and the state of things in March 1825. [FIG.3]

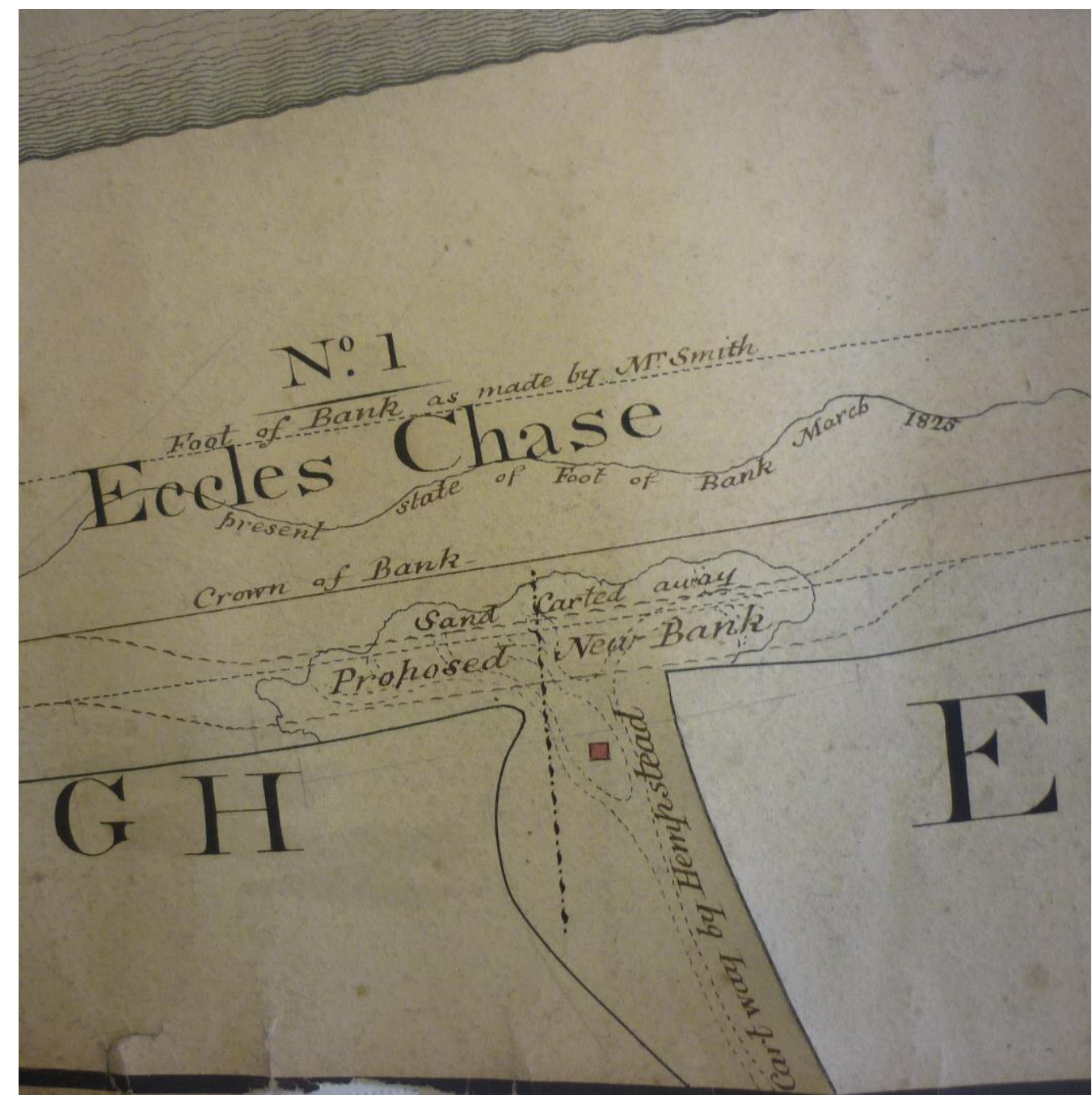


Routine acts underpinned the SBC's authority. Reports by Pratt and his successors on Eccles, in the northern section of the SBC's patch between Palling and Happisburgh, illustrate such procedures. In 1840 Pratt presented Eccles as especially vulnerable: 'this point has long been considered the most dangerous of any on the coast'. ${ }^{30}$ Before 1862 the tower of the former church of Eccles village, by then mainly lost to the sea, stood within the dunes, serving as an indicator of vulnerability, the beach before it prone to 'the alarming encroachments of the sea'. ${ }^{31}$ On 8 November 1836 Pratt met Commissioners and neighbouring farmers at Eccles to inspect a new embankment, which had withstood a recent very high tide. Assuming no grazing or removal of beach material, Pratt suggested little expense would be required, 'and certainly very little indeed, if any, to the southward of Eccles Steeple'. Pratt also offered a vision of future Commissioner control (likely never realised), protecting the low dune coast to the south: 'Raise a small Inner Embankment from Winterton Ness lights to Eccles Steeple and let all the land on the Sea side of that Embankment be the property of the Commissioners, and the heavy expenses would at once cease. This I estimate would cost about One Thousand Pounds, exclusive of the purchase of the land'. ${ }^{32}$ In his 1840 report Pratt reminded the Commissioners that while the sea had broken through the sand dunes in February 1836, the defensive embankment subsequently raised, and the prohibition of sand removal, dune grazing and marram cutting, made the site now 'perfectly safe'. 33

Erosion however continued. From 1862, after dune retreat, Eccles Steeple stood on the beach, until its fall in a storm in 1895, and became a reference point for routine defence work. In August 1864 the SBC recommended that 'another breakwater ought to be added nearly opposite Eccles Steeple',34 in July 1868 'that the breakwater near Eccles Steeple should be strengthened by sheet piling', 35 and in March 1876 (after serious winter scour) that 'Certain repairs are required to the Breakwater next Eccles Steeple', with 'nine yards bent or broken'. ${ }^{36}$ All sometimes seemed well, as in November 1885: 'The short breakwater nearest Eccles Tower has evidently done its work well, being nearly covered with sand, and the beach in its neighbourhood is in an unusually good condition. We directed some faggotting near the Tower'. ${ }^{37}$ In April 1887: 'The groynes at Eccles are very nearly covered with sand, so much so that horses could cross them', 38 while in November 1892: 'The new groynes at Eccles have effected their purpose of causing the sand to fill up the inner end of No 3 groyne and the Steeple'. ${ }^{39}$ Through the life of the SBC, rounds of inspection, maintenance and relatively minor intervention kept the coast. That the SBC also commissioned records of their work is shown after the Eccles tower fall, when Yarmouth photographer Elizabeth Miller advertised souvenir images first taken for the Commission: 'Eccles Old Tower. Very fine photographs of the above, taken by order of the Commissioners, January, 1894, can be had' 40 
The SBC also took action against those deemed to prejudice sea defence. In August 1826 SBC workman James Rands of Palling gave testimony under oath against four men (Richard Gibbs, Isaac Flowerday, John Bell and John Durrant) subsequently convicted of carting away beach material, with damages of one or six shillings plus costs imposed, ${ }^{41}$ while in 1838 a petition from residents of Hempstead and adjoining parishes to take beach material was refused. ${ }^{42}$ In October 1829: 'Mr Rising certified to the said Commissioners that Mr Silcock was taken before the Magistrates at Smallburgh for taking and carrying away sand from off the Beach at Eccles and that he was discharged on paying the damages and costs' ${ }^{43}$ Robert Rising of Horsey was then the SBC surveyor, and would from 1835 act as a Commissioner. 45 years later, names recur, minutes for March 1874 noting: 'Mr Silcock attended and explained to the Commissioners the circumstances under which he has removed materials from the Beach and it was referred to Mr Rising to mark the spot at which they may in future be taken'. ${ }^{44}$ The SBC's exercised a close, even personal authority over local affairs.

The SBC's field of vision could also move beyond the parochial. In their early years the SBC looked to outside expertise, stating in 1803: 'But that in an object of so great magnitude it is further expedient to have the opinion of one or more Engineer or Engineers of acknowledged experience and ability'. ${ }^{45}$ The SBC engaged geologist and surveyor 'Mr William Smith from Bath', who in 1801 had issued his prospectus for the first geological map of England and Wales, as engineer. ${ }^{46}$ Smith's book-length unpublished Description of Norfolk, written after his SBC work from around 1806 and dedicated to the Norfolk Agricultural Society, would present the east Norfolk coast as a region requiring defence and improvement: "The sand hills and marshes on the eastern coast, form the extremes of dreariness.... On one side blowing sands only are seen, and on the other nothing but shaking bogs. The sand hills abound with vipers, and the marshes with frogs'. Smith noted 'the total destruction with which this ... neighbourhood has long been menaced by the most alarming inundations from the ocean'. ${ }^{47}$ Smith's diaries record visiting to examine breaches between Winterton and Happisburgh from 26-31 May 1803, with further 'Sea Breach Business' between 1-7 June, meeting Commissioners at the Shire Hall in Norwich on 6 June. On 25 June Smith 'Came by sea to Waxham' to examine the sandhills, visiting Waxham Hall on 26 June, and meeting the SBC in Yarmouth on 28 June. 'Sea Breach Business' continued from 1-4 July. ${ }^{48}$ Smith's initial 1803 report identified 21 breaches at Winterton and Horsey, reflected on the origins of 'Water Gaps' in 'Wind Gaps', noted problems caused by rabbits and the carting of sand, and detailed threats to the drained 'level' inland. ${ }^{49}$ Breach repair was 'very practicable', and sandhills should be in 'a regular form and much lower than they are now', to 'lay in a proper form to receive the Impulse'. Accurate survey was needed: 'Strong stakes should be drawn into 
the slopes at low water to mark the progress of the increase or decay of the beach'.50 From May 1805 Smith was employed by the SBC 'as Engineer', preparing plans and directing repairs. ${ }^{51}$ The 1810 SBC scroll map of the coast identified 'Foot of Bank as made by Mr Smith' at Eccles, and at Horsey 'Inner Bank made by Mr Smith in 1806'.52 The SBC noted of Smith: 'he is entitled to the entire approbation of the Commissioners and the County at large'. ${ }^{53}$ In September 1808 a breach at Eccles brought further recommendations from Smith, with an urgent plan of repair given the risk of 'very considerable' damage to the level. ${ }^{54}$ Smith returned for a working week on 'Norfolk Sea Breaches' the following March, examining works 'between Happisburgh and Eccles', taking 'dimensions of all the repairs to the Sandhills'.55

Smith's diaries convey the grounding of expertise, nature knowledge of national standing applied in the locality. In 1805 Smith visited over eight months from May to December, examining 'embankment and drainage' schemes inland, advising on the enclosure of marshes, measuring inland waters and heights of tides. Three days in July-August show Smith's mix of field study, map work and meetings. On Tuesday 30 July 1805: 'At Swan Inn Norwich writing names on the general map of the Level of Marshes which is subject to damage from the water which comes in at the Breaches in the sandhills against the sea - and colouring the maps'. On Thursday 1 August 1805: 'attending the Meeting of the Commissioners at the Shire House and took instructions for making a Survey of all the lands which are liable to damage from the inundations of the sea'. On 2 August Smith travelled in 'a post chaise to Waxham Hall and thence to the Sea Breaches', met the Commissioners, examined the works in hand, saw 'the Horsey great Gap', assessed costs, 'and pointed out to the Commissioners the impropriety of cutting the marram'. Smith could also in effect act as field manager, as on 10 August 1805:

Rode down to Palling Gap and reprimanded a man who was carting sand away from out of the Gap. Rode down to the Breaches and saw the state of the works now going on ... formed a calculation of the quantity of work done to Horsey Breach and returned to Waxham. Gave the Horsey Breach Contractors an order for money and paid them $19 £$ myself'.

Smith would also make enquiries beyond the SBC, as on 24 September in Norwich: 'Went to King Street and made enquiries of Chas Hall a Waterman respecting the floods in the River and effect of inundations from the Sea Breaches'. ${ }^{56}$

Geologist (and nephew and pupil of Smith) John Phillips' 1844 memoir of the 'Father of English Geology' included a detailed account of Smith's SBC work, presenting him bringing enlightenment to a parochial region via a philosophy of natural defence: 
to make all the new artificial embankments as like as possible to the natural embankments thrown up by the sea on the same coast, to make them of the same materials, and to give them such directions as might best shelter the new work by the old. A plan so simple was almost rejected with ridicule, till, by walking on the sea-shore and pointing out to his amazed companions how ineffectual and short-lived was the resistance offered by solid constructions to the rage of the sea, and how permanent was the power of sloping banks of sand and pebbles, in particular directions, to exclude the ocean which had formed them, he convinced the most sceptical, and compelled the most contemptuous to exclaim, "Oh, that none of us should have thought of this before!" The plan was indeed simple enough, and required almost nothing but labour for successful accomplishment. ${ }^{57}$

Smith's own reports to the SBC later in his tenure however belie Phillips' picture of confident success, in May 1809 describing 'those Gaps which have recently been made' at Palling and Eccles, showing 'how serious the evil of Encroachment is becoming'. ${ }^{58}$ In his study of Smith's SBC work Peter Riches notes that after initial success Smith faced technical and financial challenges, his relative lack of sea defence experience showing, and his relationship with landowners 'increasingly fractured'. Smith's final bills were not paid until 1814, five years after his final east Norfolk work..$^{99}$ If such financial wrangles may have contributed to the SBC later becoming cautious over engaging outside expertise, their own philosophy of working with nature is echoed in Phillips' evocation of triumph: 'On these unresisting slopes the mightiest storms of the German Ocean now break harmless, and a very slight annual charge is sufficient to maintain the form and substance of the work. ... Nature's violence has here been conquered by implicit obedience to her immutable laws' ${ }^{60}$ Phillips here echoes Pratt's SBC philosophy of eight years before, noted above ('Nature may be assisted, but can seldom if ever be improved by endeavouring to alter or change her course'), and his own commentary would itself become a touchstone for Norfolk sea defence, quoted at length for example in JH Blake's 1890 Geological Society memoir on The Geology of the Country near Yarmouth and Lowestoft. ${ }^{61}$ A philosophy of nature endowed Smith, and the SBC, with nature authority.

\section{Sea Breach Critique}

A strategy of working with natural process, faggoting dunes and building groynes at key vulnerable points, continued through the nineteenth century. Two storm events in the $1890 \mathrm{~s}$ however brought critique, with the SBC presented as a body set in its ways, lacking initiative and wanting advice. Examination of these events shows the terms on which critique could proceed, and the SBC's strategy of self-defence. 
The storm of 23 January 1895 which brought down Eccles tower prompted defence debate. Rev. M.C.H. Bird, naturalist vicar of nearby Brunstead, and who would from 1900 be an SBC member, expressed fears of major inland flooding in a 5 February letter to the Norwich-based Eastern Daily Press (hereafter EDP), noting that: 'The Sea Breach Commission assemble on holy ground at Eccles on Thursday next to consider what protective steps can be taken'.62 The SBC's conclusion was that 'a good deal of damage had been done to the Sea Banks at Eccles and Little Waxham, but nothing beyond what judicious faggotting and planting of marram and some repairs to the breakwaters at Eccles would in judgement set right'.63 On 13 February F George Clements of Manor Farm, Eccles, adjacent to the former tower, wrote to the EDP criticising the Commissioners' decision to do nothing 'to strengthen the sand banks here', 64 while on 25 February WH Cooke of Stalham, journalist and local historian, wrote in the newspaper on 'Encroachments of the North Sea'. Cooke cited William Hewitt's 1844 An Essay on the Encroachments of the German Ocean Along the Norfolk Coast with a Design to Arrest its Further Depredations as offering 'valuable information that at the present crisis it would be well for the authorities to remember'. Eccles was 'the most critical point on this portion of our coast': At present nothing of any importance has been done to avert the fearful dangers to which the inhabitants of these districts are exposed to at every high tide or gale. Doubtless, some of our Sea Breach Commissioners possess Mr. Hewitt's essay. It might do them good to re-peruse it. It will be of little use crying out after the mischief has occurred. 65

The SBC gave no public response. Annual meeting minutes from November 1895 noted: 'that on $3^{\text {rd }}$ September last the Committee had again inspected the Sea Banks and found that the faggotting which they had ordered had been done to their satisfaction'.66

In late November 1897, another major storm hit the Norfolk coast, with significant damage to the dunes at Horsey, severe flooding, and a month of public debate on the SBC's role. The Horsey flood warrants extended attention, showing public argument over the geographies of authority, and suggestions for an increased role for the county or national state. The chief source for the account below, the Eastern Daily Press, styled itself as a local paper of record, but was also not averse to taking a position, in this case becoming a notable critic of the SBC. 67

On 30 November the EDP reported a 'violent and demolishing hurricane': 'The sea rose up the sandbanks, and great fears are entertained as to their safety. The sea ran mountains high. Great excitement prevailed. The wind was stronger than in the January gale of $1895^{\prime} .{ }^{68}$ On 1 December a letter from William Spelman of Great Yarmouth brought the first mention of Horsey breaches: 
'Collapse of Sea Defences. Warning to Norfolk Property Owners'. Spelman, agent for two affected estates, had seen 'two huge breaches' of 66 and 33 feet, the sea flowing through for eight hours on 29 November, flooding marshes to several feet. Spelman suggested the SBC might use their reserve of $£ 2000$ to strengthen banks: 'That they have not been kept as they should have been is no secret in the neighbourhood of this grave disaster'. Spelman had 'expected to find a hundred men at least at work', but 'was surprised to find two horses and carts, with their attendants, and fourteen labourers or so barrowing sand to the breaches'.69 Spelman's letter opened a breach for opinion, and in the following weeks SBC critics posited failure to learn lessons from history, failure to listen to local voices, failure to take adequate preventative or ameliorative action, failure to engage appropriate expertise, failure to learn lessons from abroad, and the inadequate constitution of a local amateur Commission.

History was invoked against present inaction. On 2 December WL Palmer quoted descriptions of the 1287 flood: 'The danger of a repetition of these fearful scenes recorded by the old chronicler is a real one and demands the immediate attention of those responsible for the repair of the breaches'.70 'A High-Lander' recalled FG Clements of Eccles arguing in the EDP for 'prompt action' after January 1895: 'So far as the Commission is concerned he might have sent a postage stamp'. ${ }^{71}$ The newspaper invoked Hewitt's 1844 essay alongside flood reports on 2 December, as 'an expert opinion fifty years ago', citing Hewitt on the SBC engaging 'an eminent engineer' (i.e. William Smith), the implication being that similar action might be taken now. ${ }^{72}$ Annot Wilkinson of Holt, 'Mr. Wilkinson and I, having property at Eccles', compared current work to past SBC actions, suggesting complacency: 'The present Commissioners, many of whom live inland, meet on the coast and discuss things in August, when the sea is as harmless as a pond, and, as Mr. Spelman says, they put one or two men on where gangs ought to be employed'.73 Wilkinson used 'the remains of Eccles Steeple' as a marker of decay: 'bear in mind the fact that within the last fifty years it was all but buried in the sandbanks'. This gave 'some idea of the extent to which they have been reduced and the greatly increased liability to inundation'. ${ }^{74}$

Wilkinson's allusion to 'inland' Commissioners shows another line of critique, of the Commissioners being detached from the place for which they were responsible, and inattentive to local voices. On 2 December the EDP, alongside an editorial on 'The Bombardment of the Norfolk Coast', calling for urgent repairs, ${ }^{75}$ published a report from 'special correspondents', gathering the testimony of 'several natives' at Horsey, named as Messrs Sadler, Grapes and Beckett, describing the flood, the SBC's 'apathy' and 'careless do-nothingness', their inspection in August ('Why didn't they come when they ought to?'), and their 'desultory way of sticking in a few fagots and smothering with sand'. A correspondent found two men with shovels and a cart 
at the breach: 'I never saw such child's play!' It was 'time those in authority bared their elbows and set to work'. ${ }^{76} \mathrm{~A}$ further letter from Spelman noted one of his clients planned to demand compensation. ${ }^{77}$

The newspaper's evocation, via Hewitt, of William Smith, echoed calls for outside engineering expertise, the SBC presented as single-minded and short-sighted in their devotion to faggots. On 8 December Spelman, commenting on reports of 27000 faggots used that year, noted that some were very small, half a dozen fitting under one arm: 'I would point out that there are faggots and faggots'.78 'Not King Canute', writing on 20 December as 'one having a financial interest in the threatened district', argued for professional engineering, against the SBC's 'contemptuous reference to outside criticism ... A couple of hundred pounds spent in obtaining a first-rate professional opinion would do more to allay the widespread feeling of alarm than the most positive assurances by the Commissioners of their own infallibility'..$^{79}$ Others called for comparative expertise, with Dutch coastal engineering giving lessons for Norfolk. An editorial suggested 'the advice of a Dutch engineer' be obtained, ${ }^{80}$ while Wilkinson argued that 'if necessary a practical man should be brought from Holland to give instruction in the defences' ${ }^{81}$ Late-nineteenth century debate here echoes the seventeenth century Fenland arguments discussed by Ash, where Vermuyden was presented as offering 'valuable technical expertise from the Low Countries' to 'overcome and supersede the limited conservatism of the commissions of sewers' ${ }^{82}$

Wilkinson repeated the Dutch request on 10 December, adding: 'it is not for want of funds we are kept in the constant anxiety and fear of floods, but only because the Commissioners, who are amateurs, will not properly use the means at their disposal'.83 The charge of amateurism suggested reconfiguring the geography of authority, with calls for the County Council and/or national government to take over sea defence. For Yarmouth naturalist Arthur Patterson, writing under his 'John Knowlittle' pseudonym, extensive regional flood could only be averted by the state, with Holland here offering a warning example: 'at once the attention of the Government ought to be called in, for a Norfolk Zuyder Zee would be a national disaster'. ${ }^{84}$ In a 14 December letter the EDP's 'special correspondent of December 2nd' asked: 'If the Commissioners find the job too gigantic for them to cope with, why don't they say so? Why do they not rather honestly admit it, and ask the Government to take the matter in hand'. 85 One SBC member, Edward Evans-Lombe, owner of estates at Eccles and resident at Melton Hall near Norwich, wrote to suggest the SBC's powers might be better exercised by the Norfolk County Council, as the question of sea defence was 'more than a mere local one', and the Council 'have at their disposal the services and advice of a most able civil engineer ... he, as a qualified 
professional man, would be better able to cope with dangers of this sort as they arise than private individuals' ${ }^{86}$ An editorial presented Evans Lombe's idea as worthy of consideration, ${ }^{87}$ and Spelman also wrote in support. 88

Criticism of the SBC was coupled with demands to know who and what they were. On 4 December James Hooper asked: 'But who are the Sea Breach Commissioners ...?', ${ }^{89}$ and on 6 December the newspaper printed a list of Commissioners' names, with on 11 December the SBC's legal constitution. ${ }^{90}$ The SBC, finding itself in the public eye, responded. If Evans-Lombe's letter had hardly been supportive of his own Commission, on the same day the SBC's former surveyor, the aptly initialled C. C. Rising (whose father Robert Rising, while owner of the Horsey estate, had acted as surveyor and SBC Chair) wrote to the paper. Rising, who had resigned his role in 1893 and wrote from London, criticised Spelman's 'ignorance and arrogant blame of everyone but himself', and described economical SBC defence work, sloping beaches preferable to 'apparently safer' cliffs. The public 'may rest satisfied that the safety of the district is far more secure in the hands of a well-administered Sea Breach Commission than it is ever likely to be in those of any unauthorised person, ignorant of the first principle of sea defence'. ${ }^{91}$ The next day SBC Chair T. C. Blofeld published a letter, signed only as "The Chairman of the Executive Committee of the Commissioners', stating 'facts' against 'alleged neglect'. Sandhill maintenance was 'under the immediate superintendence of gentlemen who reside on the spot', 'the proper way' being the use of thorns to collect sand: 'During this year we have used about 27,000 faggots for this purpose'. ${ }^{22}$ An editorial was sceptical over Blofeld's 'cheerful view', picking up on the 'seven and twenty thousand fagots': 'useful as fagots undoubtedly are ... it is doubtful whether, after all, they are sufficient to meet the necessities of the case'..$^{93}$ Blofeld asserted of the Horsey banks, perhaps awkwardly, that 'up to the time of the recent storm I can confidently say of it that it was never in better condition during the last fifteen nor twenty years'. The storm was unprecedented in living memory: 'it is not to be wondered that we suffered in common with our neighbours'. Blofeld argued that the SBC's response had been immediate and successful, with the breaches 'made practically safe'. The SBC were a diligent and committed body, Blofeld himself (who lived inland at Hoveton) visiting summer and winter, 'each such visit including a ten to twelve hours' day and a forty mile drive ... I repute the implication of neglect with indignation'. Unfair criticism and 'public opprobrium' after an unprecedented storm's 'providential visitation' would make it difficult 'in the future to find gentlemen willing' to serve as Commissioners. ${ }^{94}$

On 11 December the SBC held a special meeting in Norwich, reporters 'not admitted', though the EDP described proceedings. Blofeld presented arguments echoing his newspaper letter, the 
Clerk, Charles Foster, read letters from property owners threatening legal action, and the meeting passed a resolution stating that 'all reasonable precautions had been taken'. 95 There was however internal disagreement, SBC minutes recording: 'It was moved that a Deputation be sent to Holland to inspect the sea banks and ascertain if any improvements can be gathered from what is done there but on a division the motion was lost'. ${ }^{96} \mathrm{~A}$ later EDP editorial suggested that the rejected 'modest proposal' came from Blofeld, ${ }^{97}$ while the 13 December report noted that 'it was not proposed to pay the expenses of the deputation, and that idea also fell through'.98 The next day the paper's special correspondent commented: 'The Commissioners appear to be too "saving" to employ a skilled engineer, and too proud and stiff-necked to take a wrinkle from a Dutchman'. 99

Weeks of public argument concluded with a public inquiry. On 2 December Spelman had argued that 'a Government inspector be sent down at once to view the present most insecure state of our sea banks'.100 On 29 December the EDP announced: 'Captain Vereker Coming Down'.101 Vereker, a Board of Trade inspector, visited the sea banks on 30 December, and on 31 December held a public inquiry at 10.30 a.m. at the King's Arms, Martham, a large upland village inland from Horsey. Extensive reports on 1 January 1898 conveyed the terms of debate, and the attendees, including several of those involved in press correspondence, the positions of Spelman, Mr Wilkinson and Evans Lombe re-iterated in reported speeches. An editorial suggested 'imminent peril' was evident to all but the SBC, who were compared to Canute, with 'a policy which seems to be summed up in the one word "Fagots"'.102 Vereker stated that the Board of Trade had been alerted by North Norfolk Liberal MP Herbert Cozens-Hardy, acting for Garrett Taylor of Norwich, asking for a meeting 'to hear the voices of the public concerned'. 103 The 'parties interested' were represented by solicitor Louis Tillett, who outlined criticisms of the SBC, suggested expert advice was needed, and proposed an additional inner bank behind the sandhills. Rev MCH Bird suggested revisions to current policy and that a government inspector be appointed. Rising defended the SBC's work, and Blofeld presented the Commission as made up of the affected landowners, with the exception of Spelman's Horsey client, Viscount Massereene, who had only recently acquired the Horsey estate from Rising's family: 'those most deeply interested were satisfied that the right course had in the past been adopted'. Dramatic engineering was not the answer: 'Mr. Tillett said that there was no great show for the money expended. He did not desire that there should be. The best bank was the one that was almost imperceptible'. Invisibility was a virtue. 25,000 faggots 'could not be seen' as they were 'buried in sand, which showed that they had answered their purpose'. An inner bank would signal retreat, and intrude on private land and public highways. SBC surveyor Bernard Cuddon Fletcher of Somerton Hall communicated his flood repair report, noting the numbers of faggots 
used (averaging 22,000 per year), and his suggestion (not taken up) for a visit to the Dutch coast.

Vereker's summing up in effect ratified the SBC's position. Vereker rejected the idea of an inner bank ('It was a great mistake to retreat'), and stated that any expert would need to visit regularly over two or three years, as instant understanding was impossible. The SBC's policy was given support: 'Fagots he thought were an excellent protection, judiciously and largely used'. At Eccles, however, at the point where there was 'a long and steep cliff', Vereker recommended 'a revetment ..., strengthened by footings of shingle at the base of the cliffs'. After Vereker's statement Evans-Lombe, seconded by Tillett, moved that sea defence should be taken on by the County Council or national government: 'The resolution was not, however, put, and the inquiry ended with a vote of thanks to Captain Vereker'.104 Vereker as agent of the central state underwrote the SBC's local authority.

\section{Keeping on Keeping}

Vereker departed, with the SBC confirmed in its position, though under newly critical scrutiny. Some who spoke against the SBC at Martham would soon find themselves Commissioners; Bird in 1900, and Tillett in 1905, by which time he was also a Norwich Liberal MP (1904-1910). Blofeld stepped down as Chair in 1902. Local elites maintain their position, co-opting critics and adapting to circumstance.

And so the SBC kept on keeping the coast, faggots and groynes deemed feasible and sufficient. Routine works continued. Thus at Eccles in 1898 temporary defences were installed: 'a temporary short groyne from old ruins of Eccles Steeple to foot of Hills had caused the sand to be raised to top of planking'. ${ }^{105}$ In 1902 the SBC sought 'to define certain portions of the sea beach from which stones shall not be permitted to be taken, and to mark such portions by means of posts'.106 When in March 1908 Eccles beach was scoured of sand, the EDP's tone was more positive than ten years before:

At the present time the Commissioners are probably doing the best work ever carried out by that authority ... In surveying the site of this once famous fishing town one cannot help thinking of the sensation the catastrophe would have caused had it happened in our day. The bare record of the calamity is all that has come down to us and but for the vigilance of the Commissioners the same thing might occur again at any time in the region of these treacherous marram hills. ${ }^{107}$ 
Cuddon Fletcher, a Commissioner since 1867, acted as sea bank manager until resigning in 1908, reporting in November 1904: 'I find the supply of faggots obtainable is falling off. No doubt because we have been drawing steadily for eight years, upon the supply near the line of coast'. 108

From 1905 naturalist Robert Gurney, resident at Ingham Old Hall a few miles inland from Palling, acted as a Commissioner. Gurney was a serious amateur scientist, founding Britain's first fresh-water laboratory at Sutton Broad in 1902, and serving as President of the Norfolk and Norwich Naturalists' Society (NNNS) in 1912-13. Gurney sought to bring science to bear on SBC work, in collaboration with Bird, who himself became NNNS President in 1908-09.109 Gurney echoed Smith's philosophy of a hundred years earlier, backing faggots with natural philosophy in a two-page internal memorandum:

In dealing with problems of drainage and of coast defence there are two courses open: on the one hand to turn the natural forces already at work to our ends and on the other hand to endeavour to impose our will upon nature. The Commissioners have generally followed the first alternative since the second is a policy dangerous to pursue and likely to lead to unforeseen results. The great drainage schemes of the Lincolnshire fens provide a striking instance of the failure of schemes not planned in strict accordance with natural laws.

For Gurney groynes needed 'careful consideration', indeed could have 'disastrous effects', working only when 'they impose the least possible interference with the drift of tide and beach material'.110 Demonstrative defence was misguided, although sometimes there was no alternative to engineering. In a further memo Gurney detailed the loss, between 1906 and 1917, of 85 feet of land between Happisburgh and Eccles, likely due to sea bed changes cutting supplies of beach material:

In such conditions the Commissioners were powerless to effect any improvements by natural means since there was no beach material to gather and the cliff was a vertical clay face crumbling and falling with every high tide. The only thing to be done was to erect groynes, and one of these was put up in 1910 followed soon after by two more to the north. The effect was immediate.

Another was erected half a mile to the south in 1913, since when 'the whole of this stretch of beach has remained completely covered'.111

SBC Executive Committee minutes, and Gurney's diaries, convey routine acts for checking the early-twentieth century sea. The Executive Committee met on the sea banks, resolving in February 1912 that 'to spend more time on the banks and less time on the roads', for the next 
inspection 'motor cars should be used ... instead of a horsed vehicle'.112 On 9 October 1912, inspecting the sea banks north from Eccles, Commissioners viewed their labouring men: 'Eight men were at work here lowering and widening the bank by barrowing sand to the back thereby increasing the width at the top to about 20 paces'.113 In 1913 Gurney, whose beach monitoring included camera work, which he would use in reports to the SBC, photographed five men in shallow water installing a groyne, a shore landscape with labour, multiple figures balancing piling technology. On the reverse Gurney noted: 'Driving piles for new groyne at Eccles Gap. Note: planks between piles are likewise driven vertically, which is a much better arrangement than bolting them horizontally. In latter case sand is often scoured away underneath them'.114

[FIG.4]

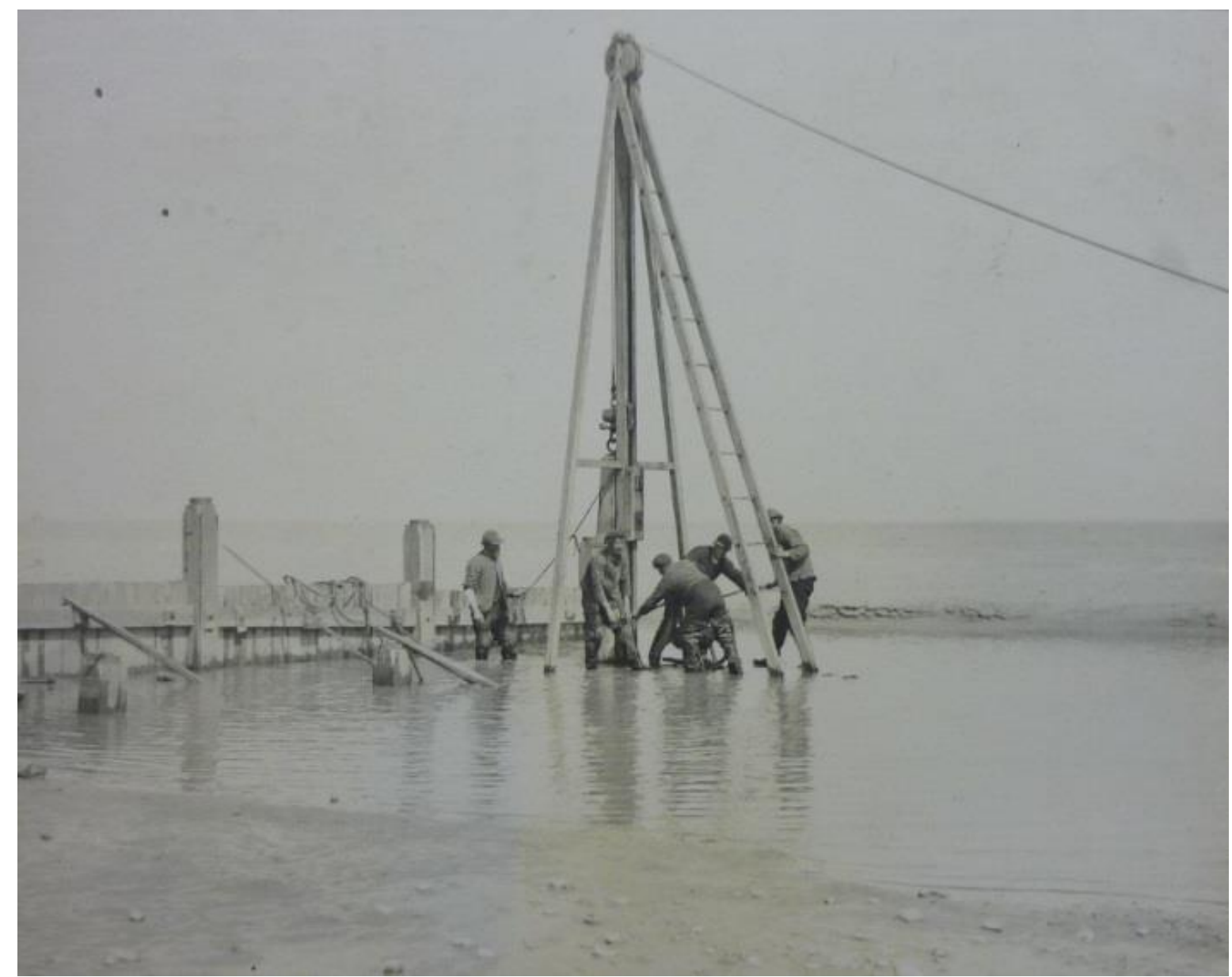

Gurney's diaries from the 1920s show how those working the beach carried historical memory to inform routine judgement. On 6 January 1922 after gales: 'Went to Eccles to see damage and met Hudson Barber there'. Barber, a farmer at Catfield, a few miles inland, had been Superintendent of Works since Cuddon Fletcher's resignation in 1908. Gurney noted: 'Remains of the road to the Church just visible. Beach not very bad and the Church well covered'. A land bank was now 'quite exposed ... This, Barber says, is the bank raised by public subscription 
about 120 years ago'. Gurney also saw lines of old fences exposed, citing Ambrose Feather, former SBC foreman and Palling fisherman: 'Feather (who was about 70 when he died this year) remembered harvesting in fields now on the seaward side of the hills. At one point where there is a bit of a bite in the clay is black and peaty for a few yards and Barber thinks this is the original outlet of what is now the Commissioners' drain. It probably does mark an old water dike'.115 SBC members and workers read the landscape, the history of their own works exposed by the sea. Gurney's investigations also however signal doubt and anxiety. On 9 January 1922 Gurney chaired a beach meeting: 'It was agreed that there is nothing to do but to let Barber carry on with patchwork'. Gurney noted: 'All recognised that we have been extremely fortunate ... There was some discussion between Bird and Barber as to the proper angle for groynes to be set'.116 On 26 January 1923 the SBC saw 'a good deal of scour lately at the Happisburgh end': 'the clay is bare, showing old dikes and land surface and the hill terribly cut about. No chance of any recovery by ordinary means'. It was agreed to erect two groynes at this 'bad danger point', the land behind being below beach level.117

Gurney's diaries also convey the social landscape of sea defence, of elite inspection and implementation by paid labour. On 28 March 1923: 'Sea Breach Comm. Visited new groyne being built to North to defend new weakspot near our boundary. Barber has done splendid work here'. Modest interventions entailed hard manual work, Barber overseeing labourers shifting sand and making groynes. The SBC members were here as elsewhere employers rather than employees, indeed sea defence workers might also serve as agricultural workers on SBC members' land, where conditions of labour could be contested. In March 1923 a major agricultural dispute had begun in Norfolk, with north-east Norfolk a strong area of union organisation. Alun Howkins notes the hard-line attitude of the farmers' leader in that area, E. G. Cubitt of Honing Hall, in the Ant valley, also a magistrate at North Walsham, and who had served on the SBC from 1891. Cubitt was a member of the Executive Committee alongside Gurney. Gurney's 28 March diary entry ends with an aside underlining the class relations shaping coastal protection, and indicating what SBC members talked about when inspections were done: 'Conversation turned a good bit to the farm strike'. 118

\section{The Sea Breach Commission and the Nature State}

Captain Vereker was not the only national state agent to visit the SBC. In the early twentieth century, as the modern nature state took shape around issues such as coastal defence and land drainage, state bodies questioned the SBC. 
In 1906 the Royal Commission on Coast Erosion was established in response to fears of land loss in an island nation, and to mitigate risks to property and trade. ${ }^{119}$ The Royal Commission called witnesses to London, took submissions from local bodies, and made field visits. The Commission scrutinised the role of Commissions of Sewers, taking evidence from Commission members and those with national experience of their work. R. F. Grantham, engineer and inspector of sea defence for the Board of Agriculture, provided a list of 22 bodies of Commissioners of Sewers which in his knowledge had sea or river frontages, mainly in the south and east of England, and gave a positive account of Commissions, 'as good bodies as can be found to look after the drainage as well as the sea defences', with landowners best entrusted to 'look after their own property'. ${ }^{20}$ Colonel R. E. Day, head of the Survey Branch of the Board of Agriculture, was however damning of Commissions, arguing for strong Board of Agriculture regulation: 'Commissions seem to become worn out'. ${ }^{121}$ Royal Commission Chairman Ivor Guest concurred with the need to rein in an archaic independence, replying to Day: 'You mean to say that these Commissions once appointed are practically independent of everybody?' 122 The line of Royal Commission critique is clear in an exchange between Day and Henry Rider Haggard, when Day suggested defence and drainage was an 'expert subject', with a particular geography:

Haggard: 'As a matter of fact the people who are appointed to the river Commissions, and so on, such as exist on the coast of Norfolk, are not experts?' Day: 'They have local knowledge'.123

The SBC were the Royal Commission's chief east Norfolk source, the Royal Commission requesting six large photographic views of sandhills and defence works. An SBC statement included in the Royal Commission report appendices outlined a rateable area of 56,300 acres, rates varying from $3 \mathrm{~d}$ to $8 \mathrm{~s}$ in the pound, referenced Hewitt's essay, Vereker's report and the relative movement of Eccles tower, and described a coast of 'erosion but no accretion', with erosion 'irregular but continuous'. ${ }^{124}$ Land agent and SBC surveyor Francis Hornor gave evidence on 16 April 1907. Hornor, responding to questioning from Haggard, asserted successful operation, with 'no incursion of the sea worth calling attention to' in 100 years, and any occasional breaches stopped, 1897 evidently falling under the latter category. ${ }^{125}$ Haggard, famous as a novelist and commentator on rural England, had detailed knowledge of this region, with a house at Kessingland in Suffolk, an estate in the Waveney valley, and a 1904 novel, Stella Fregelius, set around Eccles. ${ }^{126}$ Questions to Hornor explored the contradictions of limited jurisdiction. Asked by Commander G. C. Frederick whether the SBC ought to have requested Board of Trade permission to construct groynes, Horner stated: 'No, I think we are quite well able to know what are the requirements of the district'. A follow-up query as to whether the SBC therefore need not be consulted on proposed groyne building north of Happisburgh which 
might affect sediment movement south brought an acknowledgment from Hornor of the limitations of localism: 'Yes, I see what you mean'. When Rider Haggard suggested all Sea Breach Commissions come under the Board of Trade, Hornor responded that, even so, 'I should like the local character of the Commission preserved'. ${ }^{127}$

On Thursday 30 May 1907 the Royal Commission, guided by the SBC, inspected east Norfolk, part of the second block of the east coast inspected, from King's Lynn-Clacton, SunderlandBoston having already been covered: 'The Royal Commissioners were met by the Chairman and the Executive Committee at Eccles, and (accompanied by them) viewed the ruins of Eccles Church and inspected the works at Happisburgh'.128 The Commission had progressed around Norfolk from Saturday 25 May, with seven members, including Frederick but not Haggard, in attendance under district chairman Sir William Ffolkes. Sunday 26 was spent as Fflokes' guests at Hillington Hall near King's Lynn; Haggard's Kessingland house would be visited the following Sunday. After Wednesday night in the Hotel de Paris in Cromer, the party walked the beach to Overstrand, then motored south, with their first 'detailed enquiries' at Eccles: 'To people who are interested in the subject of coast erosion, Eccles is quite one of the famous instances'. The SBC, including Cuddon Fletcher, Barber and Hornor, walked them towards Happisburgh, inspecting a breach site from two years before: 'The mischief was repaired by hand and barrow labour, and by the planting of thorns'. The party drove on to Horsey, again observing faggot breach repairs. The EDP, reporting 'The Peril of Horsey Gap', noted a strong case for a sea wall, paralleling structures at Petten in north Holland, directly east across the North Sea. ${ }^{129}$

The Royal Commission effectively inspected not only sea defence, but the SBC. Hornor's 'Yes, I see what you mean', in response to Haggard's comment on the limits of localism, signalled an emerging political and intellectual agenda. Where the sea threatened breaches, should a national nature state supersede a local body? During the First World War national voices further intruded on SBC business. Efforts to increase agricultural production, the issue which had prompted the SBC's original formation, now undermined its constitution.

In May 1917 Gurney and Barber met Mr C. H. J. Clayton, a Board of Agriculture engineer, who was inspecting the beach from Horsey to Eccles, Gurney writing to Bird: 'The idea seemed to be to satisfy himself that, if money is spent on inland drainage, it won't be wasted by influx from the sea. I don't know if he was satisfied'.130 Clayton is noted in Michael Williams' study of the Somerset Levels as a critic of drainage administration there in 1918, and Norfolk also brought dissatisfaction. ${ }^{131}$ Clayton noted defence mechanisms including faggots, and the former use of herring swills filled with stones: 'Apparently expectations were not realised'. Former groynes at 
Horsey had been removed: 'I was unable to ascertain quite why'. The SBC had rating powers over 59400 acres: 'the responsibility of the Commission cannot be regarded as light'. A line of defence in advance of the dunes was required, with dune vegetation crucial: 'I think there might be something to be learnt from the dyke-reinforcing experiments of the Dutch and Flemish Horticulturalists and engineers'.132 Clayton here reprised a report he had made in April 1914 for the Special Commission on Arterial Drainage, to whom the SBC had applied for a Development Commission grant: 'The case does not appear to us to be one for a grant from public sources. It would appear rather to be one in which the Commissioners should seek expert advice with a view to acquainting themselves with the measure of their responsibilities and the means of discharging them'.133 In 1917 Clayton again castigated the SBC:

I confess that I am at a loss to understand why two of the four groynes at Eccles which were badly damaged by wreckage in the latter part of last year have not been repaired or replaced: why the admitted advantage to be gained by further groyning at this part of the coast has not been gained, and why, with so large and rich a rating area to draw upon for the costs of a large and continuous scheme of defence, the Commissioners do not retain the services of a competent sea-defence engineer to prepare and supervise the gradual execution of such a scheme.

The Special Commissioners were rather severe in their comments upon the attitude of the Commission; I am afraid their strictures are still justified. My own opinion is that outside pressure is needed to compel the Commission to a deeper sense of its responsibilities. ${ }^{134}$

On 15 June HC Davies, secretary of the Norfolk War Agricultural Committee, wrote to the SBC 'to ask what steps the Commissioners are taking on the matters referred to in the report, especially with reference to the two last paragraphs thereof'.135

At the same time the SBC found itself in correspondence with the private Midland and Great Northern Railway Company (MGNR), whose line between Stalham and Great Yarmouth ran along the cliffs south of Winterton. Railway representatives inspected the beach with Gurney, company engineer W. Mariott concluding: 'I think it is wonderful the way in which the sea has been fought and the banks kept intact at very little cost, but it is easy to see that this state of things cannot last very much longer unless the Commission wish to court disaster'.136 Gurney wrote to Bird on 23 June, enclosing Board of Agriculture and MGNR correspondence, presenting the latter as of little consequence, but the former as serious: "The only one of importance is the so-called report of Clayton which is very severe on us'.137 On 17 July 1917 Gurney concluded: I think myself that we ought, if only to satisfy our responsibility before the public, to call in an "expert" to report, and if necessary prepare a scheme for defence. It seems to me 
that we are open to a charge of being a party of amateurs playing with a very dangerous situation and trusting to luck year by year. We are losing ground at Eccles steadily and there is no evidence that our present methods offer any probability of averting the wastage. Of course there will be no end of opposition and mocking from Waters and Co. 138

On 24 July 1917 Gurney added: 'Was on beach at Eccles yesterday and find things rather bad. No attempt yet made to mend that groyne, though Barber has several times promised to do so'.139 Gurney's doubts over SBC capacity, and his sense that fellow executive committee members such as Charles Waters of Herringby Hall on the lower Bure, who had been elected alongside him in 1905, were unable to entertain change, indicate a body hemmed in on its own coast. For Gurney, local action began to appear insufficient. ${ }^{140}$

\section{Sandhills and Huts}

Local disputes did however gave the SBC a chance to reassert local authority in its final years, a distraction from national pressures. Thus in 1917, alongside reports from the Board of Agriculture and MGNR, Gurney received forceful communication from Commander F. S. Rogers of the Palling Royal National Lifeboat Institution, who lived at Ingham New Hall, a mile from Gurney's Ingham Old Hall. Rogers saw Eccles groynes impeding lifeboat operations: 'the groynes are useless, harmful and a waste of money'. ${ }^{141}$ The Commissioners met at Eccles and rejected Rogers' views, ${ }^{142}$ although Gurney noted to Bird that he would not object to removing old groynes, ${ }^{143}$ and that Rogers might get agreement 'if he were not so offensive about it'. ${ }^{144}$

The SBC's final years also saw more substantive sandhill debate. In the late 1920s sandhill development had become a political issue in Lincolnshire, leading to the 1932 Sandhills Act whereby Lindsey County Council assumed development control, promoting public access and amenity, and controlling hut development. ${ }^{145}$ Sea defence was a minor concern on the extensive dunes of Lincolnshire's accreting coast, but on the narrower dunes of east Norfolk hut development was seen as potentially undermining defences, and allowed the assertion of SBC authority. The SBC here faced one of its own members, Louis Tillett, their opponent in the Vereker enquiry but Commissoner since 1905. Resident at Old Catton near Norwich, Tillett was Lord of the Manor of Sea Palling. The SBC's 1907 report to the Royal Commission had stated that: 'The lords of certain manors claim rights, but these are now seldom exercised. / The lords of certain of the manors claiming foreshore rights are themselves members of the Commission and disposed to assist its work'. ${ }^{146}$ From 1928 however the SBC found a commissioner and 
manorial lord breaking ranks, unsettling collective authority, Tillett developing holiday huts in the dunes.

In May 1929 the SBC established a special sub-committee to address 'Erection of Huts on the Sea Banks', with vice-chair Bartle Frere, Barber and surveyor Bassett Hornor the active members. The Lord of the Manor was claiming 'ownership of the sandhills in Palling and the right to grant building leases', with 'numerous huts ... erected upon the sandhills at Palling and Eccles', one 'in the face of a protest raised on behalf of the Commissioners'. 147 The subcommittee interviewed Tillett on 15 June 1929, finding a 'friendly attitude',148 and on 29 June met with Tillett and other representatives of sandhill owners. The personnel overlap between regulator and regulated is striking; Mr W. R. Smith represented Cuddon Fletcher as Lord of the Manor of Little Waxham, SBC surveyor Bassett Hornor represented the Lords of the Manors of Eccles-next-the-sea and Horsey. F. G. Clements of Manor Farm Eccles was present, along with another Eccles owner, W. R. Spelman, the SBC critic of 1897.

Byelaws were proposed requiring SBC permission to erect huts, which 'on the top or on the front of the sandhills were a danger to the safety of the sandhills'. Tillett said he would act in partnership, 'but in doing so he must be the dominant partner', with 'bungalows ... allowed to be put on the land side': 'he was not prepared to submit to the prohibition of huts even on the sea side of the hills'. Tillett asserted his manorial status: 'If he did anything for Sea Palling he did not wish to have to come on his hands and knees to the Commissioners'. Frere replied that 'as far as Mr. Tillett's ownership rights went, he was the dominant partner, but without any right to control the powers of the Commissioners. So far as the exercise of the powers of the Commissioners went, there could only be one dominant authority'. ${ }^{149} \mathrm{~A}$ special general session of the SBC in Norwich on 26 October 1929 presented proposed 'Laws and Ordinances', with existing huts to stay only if granted a revocable licence by the SBC. Tillett, in poor health, sent a letter, saying he had 'personally known the sandhills for more than half a century', that they were never 'in a better condition than they are today', and suggesting he would take legal action over the 'objectionable' proposals, their 'absurdity' making the Commissioners' powers 'too arbitrary'. The SBC nonetheless proceeded, the Laws and Ordinances presented 'in parchment' and signed. ${ }^{150}$ Copies were posted on noticeboards at the gaps at Palling and Eccles, and a copy sent to each owner. The minutes of the meeting of 14 December 1929 also however reported the death of Tillett, effectively terminating the dispute.151 In December 1930 the SBC reported the regulations 'doing away with the numerous seasonal huts upon the sandhills', and tabulated the permanent licensed structures remaining; 3 huts at Palling, 1 at Eccles, 0 at Waxham. ${ }^{152}$ If in the 1920s, as discussed below, the SBC struggled to combat the national nature state, it could 
deal with a local difficulty. In clearing huts the SBC, like the sandhill authorities in Lincolnshire, acted in a manner which indeed anticipated planning authorities after 1945, tidying temporary structures from the coast. 153

\section{Sea Breach Decommissioning}

After the tabulation of huts in the SBC minutes came what would be the final report of Hudson Barber as sea bank manager:

\section{The Works, the Banks and the Beach}

The acting manager reported that the Banks were in a fairly good condition having regard to the exceptional high tides during the last few days. Some damage had been done at Horsey. At Eccles the beach had been pulled down and the groynes were empty of sand. Six men were working at Horsey repairing the banks and 4 men were planting at Palling and Eccles. Although the beach was "short" there was a lot of sand outside which he hoped the next tides would bring up. ${ }^{154}$

Such defensive routines would not however continue much longer, the national reorganisation of land drainage effectively decommissioning the SBC.

The SBC had long agreed to the establishment of new drainage boards for discrete inland areas, as long as they did not diminish their own rate-levying powers. ${ }^{155}$ More general plans were however opposed. When in 1920, following the 1918 Land Drainage Act, a new co-ordinating drainage authority, the East Norfolk Drainage Board, was proposed by Norfolk County Council, the SBC objected, with opposition to the proposal 'carried by a large majority'.156 Lack of unanimity suggests that, as with Evans Lombe in 1897, a minority of Commissioners did not oppose their own abolition. The SBC circulated their ratepayers to gather support: 'for over 100 years no serious damage has occurred, and at the present time the condition of the Commissioners' works is such as to invite inspection'. The proposed new board was 'a body mainly representing outside interests', consisting 'for the most part of members possessing no accumulated knowledge or special experience in dealing with problems of Sea-defence', and reflecting 'a desire for some large and costly scheme at the expense of the Sea Breach Ratepayers'.157 The SBC opposed the plan at a public enquiry in Norwich, opened on 31 December 1920, stating their own defence method 'did afford ample security', with the cost of alternative plans for sea walls and extensive groyning 'out of all proportion to the value of the land concerned'. The SBC's poll had shown 416 ratepayers against the new board, and 56 in favour (with a further 92 unsigned votes against, and 8 in favour). Gurney told the enquiry: 'There was no immediate danger at present at any point on the coast'.158 Further petitions were 
organised in February 1921, signatories to assert: 'I wish to oppose the inclusion of my lands in the proposed East Norfolk Drainage Board District'.159

The scheme did not proceed at this point, but from the late 1920s plans presented at a national rather than county scale proved impossible to halt. In 1929 the SBC opposed a Coast Protection Bill, enlisting Viscount Elmley, Liberal MP for East Norfolk, to speak on their behalf in the Commons. ${ }^{160}$ That Bill was withdrawn in November 1929, effectively superseded by a national Land Drainage Bill, whose passage would abolish the SBC, replacing it with the East Norfolk Rivers Catchment Board. The SBC met Elmley in the Commons on 18 June 1930, Elmley tabling amendments to the second reading of the Bill: 'There will be confusion in this Bill if it goes forward in its present form, because it mixes up coast defence and land drainage, which is as bad as mixing up salt water and fresh water'. 161 When however the Ministry of Agriculture refused SBC requests to meet, 'Lord Elmley wrote expressing his view that it was useless to resist this refusal'.162 The Land Drainage Act came into operation on 1 August 1930, the SBC continuing work until the new Board was constituted, with sea defence work taken over on 12 December 1931 by the East Norfolk Rivers Catchment Board, and responsibility for drainage behind the sandhills passing to the Happisburgh to Winterton Internal Drainage Board, whose jurisdiction extended only a few miles inland. ${ }^{163}$ The new bodies contained some old bodies, SBC member Charles Waters (presented by Gurney in 1917 as an opponent of change) becoming Chairman of the Catchment Board, and Hudson Barber acting as Vice-Chairman of the Happisburgh to Winterton IDB from its inaugural meeting in December 1935 until his death in 1938.164

A 'final general session' of the SBC took place on 20 February 1932. The minutes' final item 8, covering 'Retirement of Officers', referred to the SBC's success 'in keeping out the sea at moderate expense over a 100 years', without 'any serious loss of land' and 'in the interests of the Ratepayers', and hoped the new authority would have 'the same measure of success'; Waters as incoming Catchment Board Chair was in attendance. The SBC also looked to posterity:

Mr. Hornor said that he hoped that all the documents in the possession of the Commissioners which were of historical value would be preserved.

The Clerks reported that on handing the documents and papers over to the Catchment Board when the Transfer Order had been confirmed by the Ministry, they would suggest that the historical documents should be deposited in the proper muniment room in order that Historians could obtain access to the various documents. ${ }^{165}$ 


\section{Sea Breach Deposits}

As they rode along, a light wind had risen in the northwest and the tide started to drive up the north and west sides of the dike; but it was immediately obvious to every eye that the gentle slopes dispersed the force of the waves. The government commissioners exclaimed their astonished praise of the local dikemaster and drowned out the muttering doubts of the local commissioners. ${ }^{166}$

In Theodor Storm's 1884 novella The Rider on the White Horse, dikemaster Hauke Haien coordinates flood protection on the German North Sea coast. Storm presents a story recounted in the 1820 s of events in 1756 , the titular rider a ghostly presence on an embanked coast vulnerable to sea breach. Haien's successful gently sloping embankment becomes known as the Hauke Haien dike, and still stands after a hundred years. Haien is an innovator, building 'a dike whose waterside wall would not stand up steeply according to tradition, but would rather slope down gradually into the sea'. ${ }^{167}$ Haien, his family and his white horse are however drowned in a storm flood when the junction of the new dike and older defences is breached. Haien, against his better judgement, had listened to those who said the old dike was sound. Older ways, along with ghostly equine presences, help bring him down.

With its sea banks, visiting government commissioners, engineering differences and flood events, The Rider on the White Horse could well transplant across the nineteenth century German Ocean to east Norfolk. Death haunted Storm's coast, and also the SBC's patch. Shipwreck was not uncommon in this period, as when after the November 1897 gale the EDP reported:

Ambrose Feather, fisherman, of Sea Palling, stated that he was walking along the Beach to Eccles about seven o'clock on Tuesday morning, when he found the body amidst a quantity of wreckage. ... It was quite naked, and witness thought the man was in the rigging when the ship broke up, and that the clothes were torn off through the body being washed about.... He appeared to be between 56 and 60 years of age, and $5 \mathrm{ft} .10 \mathrm{in}$. tall. He was believed to be an Englishman. A verdict of "Accidental Death" was returned. 168

Feather would later appear in SBC accounts in 1912 as 'working foreman' for this stretch of coast. ${ }^{169}$ Storm bodies were a reminder, to the SBC and others, of the sea's capacity to overwhelm human effort. 
An east Norfolk sea breach novella would, from the sources informing this paper, feature (with the exception of Mrs. Annot Wilkinson) an entirely male cast. Authority here was a matter of gender, the SBC deploying different modes of masculine authority, derived from property ownership, expert knowledge and (for their workforce) labouring strength. The 'lines of power' evoked by Blackbourn in his study of Germany are clear in the SBC story, the protective dune line with its marram, faggots and groynes signalling a class and gender landscape of ownership, ratepaying and labour. ${ }^{170}$ Robert Pratt, William Smith, Hudson Barber, Robert Gurney and Captain Vereker offer characters for a 140 year story of judgement, ambition, authority and sea power; power to contain the sea, and the sea's power to breach defence.

Checking the sea in the twenty-first century would show a more nuanced gendered story, and one less geared around landownership. Private property remains a key but less evidently commanding element in coastal protection, not least due to the complex geographies of authority developed since 1930. If the SBC acted as a gentlemanly Commission maintaining local defences for local ratepayers, though not without local or national challenge, east Norfolk dunes are today cut across by lines of power expressing national state authority and international designation. The relationship of sea defence and land value remains central, though today less for agricultural inland value than for the nationally and internationally recognised ecological wetland value of the Norfolk Broads. Debates over technique continue, concrete walls reinforcing the dunes between Happisburgh and Winterton, and offshore granite reefs encouraging beach accumulation at Sea Palling. The 2012 Shoreline Management Plan gives 'holding the line' as the strategy between Eccles and Winterton, the ecological value of Broadland to be defended, but immediately north of Eccles the status shifts to 'managed realignment', with defences not maintained and property falling over soft Happisburgh cliffs. ${ }^{171}$

Human attempts to work natural process therefore continue in variation along the east Norfolk coast, set within new national and global narratives of sea level rise and climate change, and of an emerging Anthropocene epoch where the human presence within, and mark on, the natural world is recalibrated. Kelly, Leal, Wakild and Von Hardenberg conclude their introduction to the nature state by reflecting on possible futures, suggesting that with increasing international environmental concern and regulation 'the executive power of the nature state might increase, particularly when it is reinforced by powerful supra-state organizations and institutions'. Shifts from fossil fuel use might even make 'the nature state ... achieve the paradigmatic status desired by many environmentalists. Could the nature state become as historically and politically legible as the welfare state, or even the communist state or the capitalist state?'172 International trajectories might however be counterbalanced by a hollowing out of the national nature state, 
with UK governmental environmental bodies subject to budgetary pressure, their agency diminished under neoliberal governance. The state of the UK state at the time of writing is fluid to say the least, but it is plausible that the national nature state might become 'historically legible' less as something coming into full existence than as something apparent only at a historical distance, with the middle decades of the twentieth century showing a political formation now diminished.

If the national nature state recedes, with forms of internationalism and localism variously chipping away at its foundations, nature authorities predating its formal emergence may gain new resonance. Just as for Darby fenland drainage was a resonant story at a moment when the 1930 Land Drainage Act had finally brought administrative order, and for Grieve the history of Essex sea defence was pertinent for a time when engineering seemed finally to be triumphant ('Today the county is a walled fortress'), so the east Norfolk SBC speaks to an era of engineering caution, challenges of governance and anxieties over the human capacity to mark an Anthropocene earth, with eroding coasts recast as 'Anthroposcenic' landscapes. ${ }^{173}$ The hollowing out of public trust in scientific expertise in recent decades, and a concomitant attention to local, lay and lost knowledges, shown in studies of flood risk management, also make the SBC's story of embedded local coastal authority pertinent to the present. ${ }^{174}$ The SBC, as a constitutionally hybrid, geographically circumscribed nature authority, with limited financial resources and a philosophy of working with nature, and operating before the emergence of a coherent national nature state, may signal less a lost past than a possible future. If the concrete sea walls fall as sea level rises, might traces of thorn faggoting appear beneath the dunes?

The SBC's geographical localism crumbled as the nature state consolidated, but their sloping sands and faggoted dunes appear less distant in an age of managed realignment. For their critics the SBC muddled through in simple style, lacking bold engineering vision; for others muddling through in local fashion, with one eye on the science, might even appear a virtue. As the geographies of authority are again reconfigured, and as seas rise, the deposits of the SBC repay inspection.

\section{Acknowledgements}

Thanks to staff at the Norfolk Record Office and the Norfolk Heritage Centre (Norfolk and Norwich Millennium Library), and to David Waterhouse of Norwich Castle Museum for facilitating access to the Robert Gurney archive. 


\section{Notes}

${ }^{1}$ Alban Dobson and Hubert Hull, The Land Drainage Act, 1930 (London, 1931), p. 108; legislation also clarified that: “'Defence against water" includes defence against sea water', p. 106. 2 B. Cornford 'The sea breach commission in east Norfolk 1609-1743', Norfolk Archaeology 37 (1979), 137-145; Martin George, The Land Use, Ecology and Conservation of Broadland (Chichester, 1992), pp. 314-16; Tom Williamson, The Norfolk Broads: a Landscape History (Manchester, 1997), p. 50. For a parallel Norfolk study see Elizabeth Griffiths, 'Draining the coastal marshes of north-west Norfolk: the contribution of the Le Stranges at Hunstanton, 1605 to 1724', Agricultural History Review 63, pp. 221-242.

${ }^{3}$ Patrick Bailey, The Norwich Area (Sheffield, 1971), p. 4.

${ }^{4}$ David Matless, In the Nature of Landscape: Cultural Geography on the Norfolk Broads (Chichester, 2014), pp. 195-210.

${ }^{5}$ F. Mauelshagen, 'Flood disasters and political culture at the German North Sea coast: a longterm perspective', Historical Social Research 32 (2007), pp. 133-144; see also Tim Soens, 'Resilient societies, vulnerable people: coping with North Sea floods before 1800', Past and Present 241 (2018), pp. 143-177.

${ }^{6}$ The term 'geographies of authority' is also used by Scott Kirsch in his study of proposals for nuclear 'geographical engineering' in the mid-twentieth century United States, whereby nuclear explosives would facilitate gigantic projects of earth moving, Kirsch explores the scales at which authority is framed, and the territories thereby claimed, monitored and actually/potentially transformed; Scott Kirsch, Proving Grounds: Project Plowshare and the Unrealized Dream of Nuclear Earthmoving (New Brunswick, 2005).

7 'Report on sea-banks from Eccles to Winterton', Norfolk Record Office (hereafter NRO), EAW 2/132, 30 July 1836.

${ }^{8}$ Hilda Grieve, The Great Tide: the story of the 1953 flood disaster in Essex (Chelmsford, 1959), pp. 1-65.

${ }^{9}$ Eric Ash, The Draining of the Fens: Projectors, Popular Politics, and State Building in Early Modern England (Baltimore, 2017); H. C. Darby, The Medieval Fenland (Cambridge, 1940); H. C. Darby, The Draining of the Fens (Cambridge, 1940); see also Michael Williams, The Draining of the Somerset Levels (Cambridge, 1970), pp. 198-209.

${ }^{10}$ Ash, Draining of the Fens, p. 7.

${ }_{11}$ Darby, Medieval Fenland, p. 166-7.

12 Darby, Draining of the Fens, p. 123.

${ }^{13}$ Matthew Kelly, Claudia Leal, Emily Wakild and Wilko Graf von Hardenberg, 'Introduction', in W. von Hardenberg, M. Kelly, C. Leal and E. Wakild, eds., The Nature State (Abingdon, 2017), pp. 1-15, quotations p. 4. See also Matthew Kelly, 'The Thames Barrier: climate change, shipping and the transition to a new envirotechnical regime', in J. Agar and J. Ward, eds., Histories of Technology, the Environment and Modern Britain (London, 2018), pp. 206-229.

14 David Blackbourn, The Conquest of Nature: Water, Landscape and the Making of Modern Germany (London, 2006), p. 3, p. 6.

15 Ibid., p. 123.

16 Mike Pearson, 'In comes I': performance, memory and landscape (Exeter, 2006); M. Pearson, 'Warplands: Alkborough', Performance Research 17 (2012), 87-95; on Pearson's 'Carrlands' project see http://www.carrlands.org.uk/ (accessed 8 August 2018). See also the poetic engagement with drainage and flood archives by Hywel Griffiths, "Three poems on flood histories in rural Ireland', Cultural Geographies 25 (2018), pp. 369-374.

${ }^{17}$ Bruce Glavovic, 'On the frontline in the Anthropocene: adapting to climate change through deliberative coastal governance', in B. Glavovic, P. Kelly, R. Kay and A. Travers, eds., Climate 
Change and the Coast: Building Resilient Communities (London, 2015), pp. 51-99; D. Matless, 'The Anthroposcenic', Transactions of the Institute of British Geographers 42 (2017), pp. 363-376.

18 Cornford, 'Sea breach commission', p. 142.

19 William Marshall, The Rural Economy of Norfolk (London, 1795, second edition), p. 206.

20 Ibid., p. 201.

21 Ibid., p. 202.

22 Ibid., pp. 204-5.

23 'Resolutions of the Sea Breach Committee', NRO, EAW 2/39, 29 April 1803.

${ }^{24}$ Robert Gurney Archive, Norwich Castle Museum (hereafter RGA), 132.950.24, Box 1, File 3.

The Faden map also showed 'Breaches filled up' between Eccles and Palling; on the Faden map see J. C. Barringer, Faden's Map of Norfolk (Dereham, 1989); Andrew Macnair and Tom Williamson, William Faden and Norfolk's Eighteenth Century Landscape (Oxford, 2010).

25 P. Riches, 'A breach too far? East Norfolk's place in William Smith's search for success', Earth

Sciences History 35 (2016), 145-166; Williamson, Norfolk Broads.

26 Grieve, The Great Tide, 31.

${ }^{27}$ Francis Hornor, Letter to Chair of SBC, 2 November 1907; Robert Gurney, undated memorandum; both in RGA, 132.950.24, Box 1, File 3.

28 NRO, EAW 2/26, 15 July 1837.

${ }^{29} \mathrm{NRO}, \mathrm{HNR} / \mathrm{P} 4 / 1 ; \mathrm{HNR} / \mathrm{P} 4 / 2$.

${ }^{30}$ NRO, EAW 2/135, 26 September 1840; on Eccles see D. Matless, 'Next the Sea: Eccles and the Anthroposcenic', Journal of Historical Geography 62 (2018), pp. 71-84.

31 'Mr. William Smith's report of sea breaches', NRO, EAW 2/128, May 1809.

32 NRO, EAW 2/133, 25 November 1836.

33 NRO, EAW 2/135, 26 September 1840.

34 NRO, EAW 2/26, 27 August 1864.

35 NRO, EAW 2/26, 18 July 1868.

${ }^{36}$ NRO, EAW 2/27, 11 March 1876.

37 NRO, EAW 2/27, 7 November 1885.

${ }^{38}$ NRO, EAW 2/27, 30 April 1887.

${ }^{39}$ NRO, EAW 2/27, 5 November 1892.

40 Eastern Daily Press, 28 January 1895, p. 4; Matless, 'Next the Sea'.

${ }^{41}$ NRO, EAW 2/39, 4 August 1826; NRO, EAW 2/26, 12 August 1826.

42 NRO, EAW 2/26. 24 March 1838.

${ }^{43}$ NRO, EAW 2/26, 22 October 1829.

${ }^{44}$ NRO, EAW 2/126, 14 March 1874.

45 NRO, EAW 2/39, 29 April 1803.

${ }^{46}$ NRO, EAW 2/120, 1803; Riches, 'Breach too far'; Simon Winchester, The Map that Changed the

World: William Smith and the Birth of Modern Geology (New York, 2001).

47 William Smith, Description of Norfolk, unpublished and undated, p. 7-8; online at www.oum.ox.ac.uk, WS/F/4/3/001.

${ }^{48}$ Smith's diaries, in the Oxford Museum of Natural History, are online at www.oum.ox.ac.uk.

49 'Report of Mr. William Smith upon the sea breaches', NRO, EAW 2/120, 1803.

50 Letter, Smith-SBC, NRO, EAW 2/119, 6 June 1803. Riches however notes that Smith, contrary to what would become SBC policy, did not recommend faggots to catch sand; 'Breach too far', p.

162

${ }^{51}$ NRO, EAW 2/29, 4 May 1805.

52 NRO, HNR/P, $4 / 1$.

53 NRO, EAW 2/29, 31 May 1806.

${ }^{54}$ NRO, EAW 2/39, 4 December 1808.

55 William Smith, 1809 diary, WS/B/008, www.oum.ox.ac.uk.

56 William Smith, 1805 diary, WS/B/005, www.oum.ac.uk.

57 John Phillips, Memoirs of William Smith (London, 1844), p. 53.

58 NRO, EAW 2/128. May 1809.

${ }^{59}$ Riches, 'Breach too far', p. 148; NRO, EAW 2/26. 
60 Phillips, Memoirs, 53.

${ }^{61} \mathrm{~J}$. H. Blake, The Geology of the Country near Yarmouth and Lowestoft (London, 1890), pp. 71-2; Phillips's passage also appears, as a quotation from Blake, after the 1938 Horsey floods, in J. E. Sainty, 'Past History of Sea Flooding and Cause of the 1938 Flood', Transactions of the Norfolk and Norwich naturalists' society 14 (1939) pp. 334-345.

62 EDP, 5 February 1895, p. 6.

${ }^{63}$ NRO, EAW 2/27, 30 November 1895.

${ }^{64}$ EDP, 13 February 1895, p. 5.

${ }^{65}$ EDP, 25 February 1895, p. 3; W. H. Cooke, Eccles next the Sea, Norfolk and the Erosion of the East Coast (Stalham, 1908); W. Hewitt, An Essay on the Encroachments of the German Ocean Along the Norfolk Coast with a Design to Arrest its Further Depredations (Norwich, 1844). ${ }_{66}$ NRO, EAW 2/27, 30 November 1895.

${ }^{67}$ Grieve, The Great Tide, pp. 42-50, discusses the impact of the 1897 storm in Essex, with over 30000 acres flooded. On the more extensive 1938 flood at Horsey see Matless, In the Nature of Landscape; D. Matless, 'Accents of landscape in GPO Country: The Horsey Mail, 1938', Twentieth Century British History 23 (2012), pp. 57-79. On the EDP as paper of record see D. Matless, 'Original Theories: science and the currency of the local', Cultural Geographies 10 (2003), pp. 354-378.

68 EDP, 30 November 1897, pp. 4-5.

${ }^{69}$ EDP, 1 December 1897, p. 5.

70 EDP, 2 December 1897, p. 3

${ }^{71}$ EDP, 3 December 1897, p. 3; on the same page the newspaper reprinted a letter of 26 January 1895 from S Waters Spelman (perhaps a relation of William) arguing for SBC action.

72 EDP, 2 December 1897, p. 5. On 22 December further extracts from Hewitt's 1844 essay were reprinted as 'Our Sea Defences - Records of Old Breaches', p. 5, extracts from Hewitt,

Encroachments, p. 50.

73 EDP, 7 December 1897, p. 5; a further letter from Wilkinson on 10 December refers to their land and 'a large house' at Eccles.

${ }^{74}$ EDP, 11 December 1897, 6.

75 EDP, 2 December 1897, p. 4.

76 EDP, 2 December 1897, p. 5.

77 EDP, 2 December 1897, p. 5; on 9 December the EDP reprinted a telegram sent the previous evening by Spelman on the state of the breaches during gales, effectively using him as a reporter, p. 5.

78 EDP, 8 December 1897, p. 5.

${ }^{79}$ EDP, 20 December 1897, p. 5.

${ }^{80}$ EDP, 7 December 1897, p. 4.

${ }^{81}$ EDP, 7 December 1897, p. 5; James Hooper also wrote suggesting varieties of dune grass in

Holland had greater strength, and might therefore be used, 4 December 1897, p. 8.

82 Ash, Draining of the Fens, p. 309.

83 EDP, 10 December 1897, p. 3.

${ }^{84}$ EDP, 3 December 1897, p. 3.

85 EDP, 14 December 1897, p. 3.

86 EDP, 6 December 1897, p. 5.

87 EDP, 6 December 1897, p. 4.

88 EDP, 8 December 1897, p. 5.

89 EDP, 4 December 1897, p. 8.

90 EDP, 6 December 1897, p. 5; EDP, 11 December 1897, p.5.

${ }^{91}$ EDP, 6 December 1897, p. 5; Rising would write again on 18 December against 'alarmist' and 'irresponsible' critics, p. 3.

92 EDP, 7 December 1897, p. 5.

93 EDP, 7 December 1897, p. 4.

${ }^{94}$ EDP, 7 December 1897, p. 5.

95 EDP, 13 December 1897, p. 5. 
${ }_{96}$ NRO, EAW 2/27, 11 December 1897.

${ }^{97}$ EDP, 1 January 1898, p. 4

98 EDP, 13 December 1897, p. 5.

${ }^{99}$ EDP, 14 December 1897, p. 3; the EDP's report that a proposed appointment of an engineer was met with 'general disapproval' was itself corrected by a letter the next day from the Clerks to the Commissioners, who stated the Executive had been given full power to call in an engineer 'whenever they deemed it necessary', 14 December 1897, p. 3.

100 EDP, 2 December 1897, p. 5.

101 EDP, 29 December 1897, p. 5.

102 EDP, 1 January 1898, p. 4.

103 EDP, 1 January 1898, p. 5; the EDP had published a letter from Taylor critical of breach repairs on 18 December 1897, p.3.

104 EDP, 1 January 1898, p. 5.

105 NRO, EAW 2/152, March 1898.

106 NRO, EAW 2/27, 1 November 1902.

107 EDP, 19 March 1908, p. 4.

108 NRO, EAW 2/27, 19 November 1904.

109 Matless, In the Nature of Landscape.

110 RGA, 132.950.24, Box 1, File 3, undated.

111 RGA, 132.950.24, Box 1, File 3, undated, 1917 or later.

112 NRO, EAW 2/35, 27 February 1912.

113 NRO, EAW 2/35, 9 October 1912.

114 Gurney's Eccles photographs are held in the Norfolk Photographic Survey collection, Box EECC, Norfolk Heritage Centre, Norfolk and Norwich Millennium Library, Norwich, and will be discussed in a further paper on his work. Gurney would for example show photographs of scour at Eccles in reporting to the SBC Executive Committee on 18 December 1915, NRO, EAW 2/35. 115 Robert Gurney, Diary, 6 January 1922, pp. 7-8. The RGA holds yearly diaries from 1922-29.

116 Robert Gurney, Diary, 9 January 1922, p. 9.

117 Robert Gurney, Diary, 26 January 1923, pp. 2-3.

118 Robert Gurney, Diary, 28 March 1923, p. 12; Alun Howkins, Poor Labouring Men: Rural Radicalism in Norfolk 1870-1923 (London, 1985), pp. 154-175.

119 James Winter, Secure from Rash Assault: Sustaining the Victorian Environment (Berkeley, 1999), pp. 231-248.

120 Royal Commission on Coast Erosion, Volume I (Part II) Minutes of evidence and appendices (London, 1907), Cd. 3684, quotations p. 252, p. 249. Grantham gave evidence on 5 February 1907. His list appears in Appendix XXIVa, p. 353. A further list, provided by Noel Kershaw of the Local Government Board, identified 69 'Sewers Commissions and Drainage Boards in England and Wales Whose Districts Abut Upon the Coast'; Appendix IX, pp. 133-137.

${ }^{121}$ Royal Commission on Coast Erosion, Volume I (Part II) Minutes of evidence; p. 74. Day gave evidence on 18 October 1906.

122 Royal Commission on Coast Erosion, Volume I (Part II) Minutes of evidence, p. 75.

123 Royal Commission on Coast Erosion, Volume I (Part II) Minutes of evidence, p. 81.

124 Royal Commission on Coast Erosion, Volume I (Part II) Minutes of evidence; the SBC report appears within Appendix XXIII, 'Return from Local Authorities, Etc., in England and Wales giving certain information with regard to erosion and accretion in their respective districts', pp. 23940; see also NRO, EAW 2/27, 15 December 1906; NRO, EAW 2/27, 7 December 1907.

125 Royal Commission on Coast Erosion, Volume I (Part II) Minutes of evidence; Hornor's evidence appears on pp. 324-332; quotation p. 326. Hornor was also appearing on behalf of the

Surveyors' Institution.

126 Matless, 'Next the sea'.

127 Royal Commission on Coast Erosion, Volume I (Part II) Minutes of evidence, p. 331.

128 NRO, EAW 2/34, 30 May 1907.

129 EDP, 31 May 1907, p. 5.

130 Letter, Gurney-Bird, NRO, HMN 7/319/14, 11 May 1917. 
131 Williams, Somerset Levels, p. 230.

132 NRO, HMN 7/319/14, 11 May 1917.

133 NRO, HMN 7/319/14, 9 April 1914.

134 NRO, HMN 7/319/14, 11 May 1917.

135 NRO, HMN 7/319/14, 15 June 1917.

136 NRO, HMN 7/319/14, 23 May 1917.

137 NRO, HMN 7/319/14, 23 June 1917.

138 NRO, HMN 7/319/14, 17 July 1917.

139 NRO, HMN 7/319/14, 24 July 1917.

${ }^{140}$ Gurney would leave Norfolk in June 1928, moving to Boars Hill outside Oxford, and

recording in his diary on 31 December 1928: 'We rejoice too in the change of society. Here we have nice and congenial people all round us, so different from the Norfolk people ... Altogether the move has been a triumphant success', p. 41. SBC minutes of 15 December 1928 state: 'The Chairman reported that Mr Robert Gurney had left Norfolk to reside in Oxfordshire and had written resigning his appointment as Vice-Chairman'; NRO EAW 2/28.

141 NRO HMN 7/319/13, 773 x 6, 8 February 1917.

142 NRO HMN 7/319/13, $773 \times 6$ 6, 25 January 1917.

143 NRO HMN 7/319/13, 773 x 6, 15 February 1917.

144 NRO HMN 7/319/13, 773 x 6, 27 February 1917.

$145 \mathrm{~J}$. Sheail, 'The impact of recreation on the coast: the Lindsey County Council (Sandhills) Act, 1932, Landscape Planning 4 (1977), pp. 53-72; Sophie Hollinshead, "No-Mans Land"? The contested landscapes of the North Lincolnshire sandhills', MA Landscape and Culture Dissertation, University of Nottingham School of Geography, 2009.

146 Royal Commission on Coast Erosion, Volume I (Part II) Minutes of evidence and appendices, Appendix XXIII, p. 240.

147 NRO, EAW 2/28, 15 December 1928.

148 NRO, EAW 2/38, 15 June 1929.

149 NRO, EAW 2/38, 29 June 1929.

150 NRO, EAW 2/28, 26 October 1929.

151 NRO, EAW 2/28, 14 December 1929.

152 NRO, EAW 2/28, 13 December 1930.

153 Dennis Hardy and Colin Ward, Arcadia for All: the Legacy of a Makeshift Landscape

(Nottingham, 2004, first published 1984).

154 NRO, EAW 2/28, 13 December 1930.

155 NRO, EAW 2/28; new boards were thus approved at Raveningham in the Yare Valley in 1915, on the Halvergate marshes in 1923, around Acle New Road in 1928, and on the Upper Bure and Waveney Valley in 1929.

156 NRO, EAW 2/28, 21 February 1920.

157 NRO, EAW 2/28, 11 December 1920.

158 EDP, 1 January 1921; copy in RGA, 132.950.24, Box 1, File 5.

159 RGA, 132.950.24, Box 1, File 5; petitions were organised by Robert Gurney's brother Eustace, of Sprowston Hall, for the upper Wensum, and by CB Lucas of Filby House for the lower Bure,

Yare and Waveney.

160 NRO, EAW 2/28, 26 October 1929, 14 December 1929.

161 Hansard, 24 June 1930, 7 p.m.; NRO, EAW 2/28, 13 December 1930.

162 NRO, EAW 2/28, 13 December 1930.

163 NRO, EAW 2/28, 25 July 1931.

164 Happisburgh to Winterton Internal Drainage Board minute book, 1935-1943, Water

Management Alliance archive, King's Lynn. The Catchment Board archives are held in the

Norfolk Record Office.

165 NRO, EAW 2/28, 20 February 1932.

166 Theodor Storm, The Rider on the White Horse (New York, 2009, first published 1884), p. 258.

167 Ibid., p. 243. On dike law and management on the German North Sea coast see Mauelshagen, 'Flood disasters'. On parallels across the North Sea see Greg Bankoff, 'The 'English Lowlands' 
and the North Sea basin system: a history of shared risk', Environment and History 19 (2013), pp. 3-37. On the contemporary resonance of Storm see Katie Ritson, 'Engineering the Anthropocene: Technology, Ambition, and Enlightenment in Theodor Storm's Der Schimmelreiter', in S. Wilke and J. Johnstone, eds., Readings in the Anthropocene (London, 2017), pp. 222-242; Katie Ritson, The Shifting Sands of the North Sea Lowlands: Literary and Historical Imaginaries (London, 2019).

168 EDP, 4 December 1897, p. 5.

169 NRO, EAW 2/35, 27 February 1912; NRO, EAW 2/35, 9 October 1912.

170 Blackbourn, Conquest of Nature, p. 6.

171 Kelling to Lowestoft Ness Full Shoreline Management Plan, 2012, 100; see also Kelling to Lowestoft Ness Shoreline Management Plan: Non Technical Summary, 2012, 9-10. The plans are available on the website of the East Anglia Coastal Group, www.eacg.org.uk. See also Matless, 'Next the sea'; R. Kerry Turner and Tiziana Luisetti, 'Toward adaptive management in coastal zones: experience from the eastern coastline of England', in B. Glavovic, P. Kelly, R. Kay and A. Travers, eds., Climate Change and the Coast: Building Resilient Communities (London, 2015), pp. 417-434; T. O'Riordan, C. Gomes and L. Schmidt, 'The difficulties of designing future coastlines in the face of climate change', Landscape Research 39 (2014), pp. 613-630.

172 Kelly et al, 'Introduction', p. 12.

173 Grieve, The Great Tide, p. 1; Matless, 'The Anthroposcenic'.

174 Graham Haughton, Greg Bankoff and Tom Coulthard note that in the 2007 floods the Internal Drainage Boards set up after the 1930 Land Drainage Act were upheld by some as 'repositories of historically embedded knowledge', in contrast to the seemingly remote national Environment Agency; G. Haughton, G. Bankoff and T. Coulthard, 'In search of 'lost' knowledge and outsourced expertise in flood risk management', Transactions of the Institute of British Geographers 40 (2015), pp. 375-386, quotation p. 379.

\section{Checking the Sea: Figure Captions}

1. 'Sketch panorama of the map area from a theoretical viewpoint off Great Yarmouth', from Patrick Bailey, The Norwich Area: A description of the O.S. One-inch Sheet 126: Norwich (1971, p. 4), published by the Geographical Association in their 'British Landscapes Through Maps' series.

2. Sketch map by Robert Gurney showing sea breaches prior to 1792, undated but produced in the early twentieth century; Robert Gurney Archive, Norwich Castle Museum, 132.950.24, Box 1, File 3, CNorfolk Museums Service/Norwich Castle Museum \& Art Gallery.

3. Detail from Eccles section of 1810 Sea Breach Commission scroll map of the east Norfolk coast; Norfolk Record Office, HNR/P 4/1.

4. 'Driving piles for new groyne at Eccles Gap', photograph by Robert Gurney, 1913; Norfolk Photographic Survey Collection, Box E-ECC, Norfolk Heritage Centre, Norfolk and Norwich Millennium Library, Norwich. 